\title{
“To Promote the General Welfare": Addressing Political Corruption in AmericA ${ }^{\mathrm{I}}$
}

\author{
Bruce M. Owen* \\ Stanford University, USA
}

\begin{abstract}
Systemic (but lawful) political corruption reduces well-being and equity in America. The original form of Madisonian democracy is no longer capable of containing such corruption. Proposals currently on the table to stem corruption are unlikely to be effective and tend to undermine basic rights. This Essay describes a new, but still Madisonian, approach-regulating the output of corrupted legislative and administrative processes, rather than the inputs. Providing for substantive ex post review of direct and delegated legislation would be far more protective of the "general welfare" of the People than other reforms, while no more or less difficult to implement. Supporting an "umpire" branch may be a dominant strategy for elites themselves.
\end{abstract}

\section{CONTENTS}

I. INTRODUCTION ............................................................... 5

II. BACKGROUND ................................................................. 7

III. LAWFUL CORRUPTION .................................................. 16

IV. The Framers’ objectives .............................................. 24

V. Potential Remedies for political corruption..................28

A. Broaden the reach of criminal law.................................. 28

B. Campaign finance reform .......................................29

C. Tighten regulation of lobbying .................................... 32

1 I am grateful to numerous colleagues, students and friends for important insights and encouragement, over an extended period. I am indebted to Jason Bade, Jonathan Bender, Bruce Cain, Seth Cooper, Francis Fukuyama, Josh Freedman, Harold Furchtgott-Roth, Robert Gibbons, Larry Goulder, Justin Hefter, Larry Kramer, Brian Lamb, Sam Larson, Lawrence Lessig, Randolph May, Madeleine McKenna, John P. McCormick, Roger Noll, Teryn Norris, Josetta Owen, Peter Owen, Jack Rakove, Sam Rebo, Otis Reid, Greg Rosston, Sara Rowe, Richard Saller, and Barry Weingast. I apologize to those whom I may have overlooked.

2 Bruce M. Owen is the Morris M. Doyle Centennial Professor in Public Policy, Emeritus, Stanford University, and Senior Fellow, Emeritus, Stanford Institute for Economic Policy Research. Email: bruceowen@stanford.edu. 


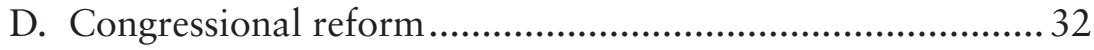

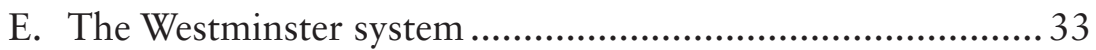

F. The presidential veto and the unitary executive.................... 34

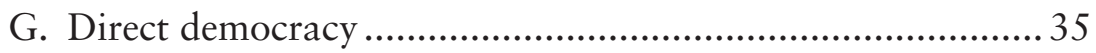

H. Limited government .......................................................... 36

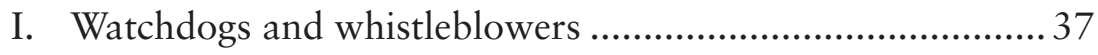

VI. QUALITY CONTROL-IN BUSINESS, SPORTS, AND POLITICS .......... 37

A. Substantive review in the Supreme Court ............................. 41

B. Agencies responsible for policy evaluation: $\mathrm{OMB}$,

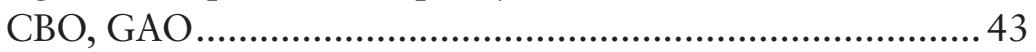

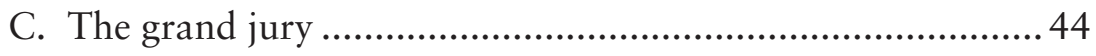

D. Umpires of the past .............................................................. 45

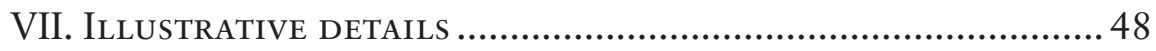

A. The Umpire Amendment ................................................... 49

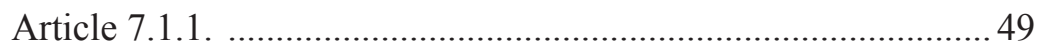

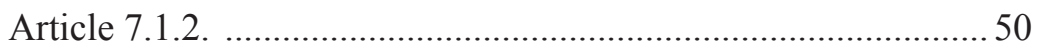

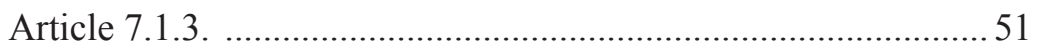

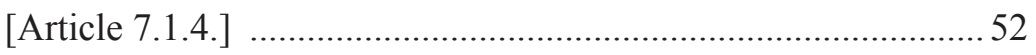

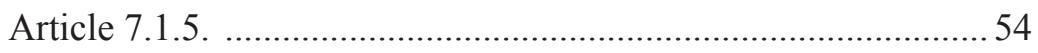

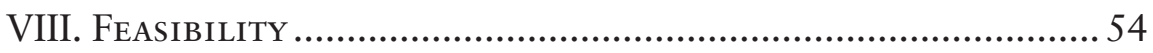


The inference to which we are brought is, that the CAUSES of faction cannot be removed, and that relief is only to be sought in the means of controlling its EFFECTS.

THE FEDERALIST NO. 10 (James Madison)

\section{INTRODUCTION}

Systemic, institutional, or "type 2" lawful political corruption is a serious problem. It misallocates resources, undermines trust in government, and contributes to the growing gap between the rich and the poor. Systemic corruption occurs when political representatives routinely face options that advance their own interests at the expense of the public, and for which there is little or no personal or political risk. Many Americans are contemptuous of politicians because they appear to be for sale. People distrust Congress in particular. Why is this and what can we do about it?

It is difficult to avoid the suspicion that there is something wrong with the structure of government. After all, the constitutional design ratified in 1788 is largely unchanged. The natural inclination of elected officials to serve their own interests at the expense of the public interest probably has changed little over the years. Politicians have always been seen as rascals. The Madisonian system was once widely admired but now seems to be failing us. If corruption is a more serious problem today than in the past, perhaps it is because Madisonian democracy is less effective at containing it.

James Madison and his colleagues were well aware of the problem of corruption. They understood that elected officials face an unavoidable conflict of interest between the public welfare and their own careers. The Framers also had a realistic view of how interest groups affect government policy. It was, and remains, perfectly obvious that if there is an organization that has the power to grant benefits to one group of citizens at the expense of others, members of each group will want to influence that organization's policies. It is not shocking that interest groups matter in policy making. Any form of government, when compared with the alternative of Hobbesian dystopia, requires the support of elite interests to which the Hobbesian alternative appears only somewhat less attractive. Such elites require ongoing favorable treatment by the government.

Madison addressed the problem of "faction" (interest groups) in The Federalist No. 10. He recognized that powerful factions could influence political outcomes in unhealthy ways, including repression of the interests of less powerful or less well organized, but possibly more numerous, citizens. He argued that a strong central government would be better able to control such factions (as compared to individual states) because the number of competing interests would be greater at the national level. Madison also held that the separation of powers, the ability of citizens to discipline 
political misbehavior through frequent elections, and the limited scope of government itself would help to suppress corruption.

Successful candidates for congressional seats have some combination of the following characteristics: expertise in campaign strategy and operations, high levels of name recognition, sufficient funding to purchase advertising and other campaign resources, local support groups (e.g., parties or interests) willing to help with canvassing, and positions on high-salience issues that are consistent with those of a majority of voters in the primary and general elections. Equally important, of course, is the failure of rival candidate(s) to have these same characteristics in greater measure. Discussions of the importance of money in politics often seem to assume that money is the only thing that matters. Not true. However, it is useful to assume, for the sake of discussion, that all the candidates do the best they can to run an effective campaign, given the money and related support that they command. In that context, money and the resources it can buy makes all the difference between winning and losing.

Campaign donors (or "independent" supporters) can help a candidate by giving or spending money for the candidate, or by not giving or spending money in support of rival candidates. An interest group can influence a candidate or an incumbent seeking reelection without spending a penny in support of that candidate simply by supporting or threatening to support the rival candidate.

Unfortunately, in practice, elections do not effectively discipline systemic corruption. Candidates require several attributes to succeed, but one is indispensable: money. Voters are not inclined to try to assess candidates' contributions to public well-being. The task is beyond the capability of any voter, however well-informed or diligent. Moreover, elections are biased in favor of the same powerful interests that corrupt legislation because these interests also finance campaign advertising.

It is good that elected officials are responsive to interest groups. That is why the First Amendment has its Petition Clause. However, both legislation and the administration of interventions are vulnerable to corruption because important interests are unable to participate in the process; those interests are diffused, difficult to organize, or lack the resources to invest in political action. Further, neither the judiciary nor the President is in the business of blocking corrupted, welfare-reducing legislation. Finally, most corrupted legislation is obscure, hidden in important unrelated bills, and devoid of interest to the media and media audiences. The canonical checks and balances simply do not work in stemming non-salient, welfare-reducing, and redistributive legislation and regulation.

A major purpose of any democratic government is to provide an arena in which interest groups can reach peaceful solutions to conflicts. The constitutional regulation of this struggle in a Madisonian democracy consists in defining and protecting certain minority rights that the government may not sacrifice to majority demands. Madisonian minority protections are general purpose: they protect not only disadvantaged or unpopular interests but also very powerful minorities with ample resources to influence government policy. Because of these protections, we cannot regulate interest groups and their influence on legislation except through elections or pushback from the other 
two branches. Regulation that is more direct tends to invade foundational rights that serve important general constitutional purposes.

Systemic political corruption is costlier today than in 1788 because the substantive jurisdiction of the federal government is no longer limited. Washington now regulates nearly every form of human interaction, economic and social. This provides a virtually unlimited menu of opportunities for elite interests and political representatives to design mutually beneficial interventions, the cost of which is borne mostly by the non-elite. Consequently, government often sacrifices the welfare of the poor, the middle class, and perhaps even the elite as a class, to individual elite interests. Not only is the elite share of the pie increased, but also the process shrinks the size of the pie. In the end, everyone may be worse off.

The usual suggestions for reform of the system include tinkering with election or lobbying practices. These are not likely to be successful because they do little to redress the imbalance of interests that contributes to corruption. As the epigraphic quotation from Madison's The Federalist No. 10 suggests, when reform of the process is not feasible, we must turn our attention to policing the effects.

When the frequent effect of legislation or regulation is to make the people as a whole worse off, or to make each faction of the elite better off at the expense of everyone else, the democratic process has either erred or failed. ${ }^{3}$ There is good reason to veto such law and regulation because better alternatives (among them the status quo) always exist. The reality is that the rival branches are unmoved by welfare-reducing legislation or regulation, and elections are ineffective in penalizing lawful corruption. A different institution or branch therefore must provide a remedy in the form of effective checks and balances to protect the general welfare. This Essay proposes a general solution and, for clarity, a concrete illustration of how to do that.

\section{BACKGROUND}

Many political philosophers (with such notable exceptions as Plato) have endorsed democracy as a superior method of governance. Winston Churchill rather glibly characterized democracy as a terrible system but better than

3 See Richard B. Stewart, Madison's Nightmare, 5 U. CHI. L. Rev. 335, 340 (1990) ("It is now widely understood that the processes through which national measures are adopted and enforced do not always ensure that assertions of national power serve the general interest. Instead, they can invite the very domination by faction that Madison so desired to prevent.") 
the alternatives. ${ }^{4} \mathrm{~A}$ democracy is a society governed by the will of its people. A people's will is slippery, vague, fickle and ephemeral. It may be more realistic to say that democracy is a society governed by whatever voters will put up with. What matters to people, of course, is what has always mattered: well-being and justice, or as the Framers put it, life, liberty, and the capacity to pursue happiness. A democracy can claim to be "best" only to the extent that it delivers on these objectives.

"All political systems are prone to decay over time." ${ }^{5}$ Constitutions can be social contracts or peace treaties among contending interests. Nevertheless, if the legitimacy of a constitution rests on the will of the People, and if the People's will is inconstant, it follows that the constitution (or at least its interpretation) must also change. America's Madisonian democracy is no exception. Shortly after the 1787 publication of the proposed new Constitution, Thomas Jefferson expressed the view that the preservation of liberty might require a bloody revolution in each generation and thus a new Constitution. ${ }^{6}$ However, violent change has obvious costs and offers no assurance that the well-being of the People will improve. Plenty of revolutions have produced bad outcomes for the people: Russia in 1917 is a good example.

One reason to modify a democratic constitution is to reduce the costs of political corruption. Corrupt law, including administrative rules and procedures, reduces aggregate well-being, or produces regressive redistribution, or both. Political corruption encompasses far more than criminal acts of bribery or extortion. ${ }^{7}$ It includes other, lawful, behavior that undermines public trust

4 "Many forms of Government have been tried, and will be tried in this world of sin and woe. No one pretends that democracy is perfect or all-wise. Indeed, it has been said that democracy is the worst form of government except all those other forms that have been tried from time to time ..." 444 Parl Deb HC (5 $5^{\text {th }}$ ser.) (1947) col. 206-07.

5 Francis Fukuyama, Political Order and Political Decay 35 (2014).

6 Jefferson at one point apparently favored a revolution and a consequent new constitution for each generation: "The tree of liberty must be refreshed from time to time with the blood of patriots and tyrants. It is its natural manure." Letter from Thomas Jefferson to William Smith (Nov. 13, 1787), available at http://www.loc.gov/exhibits/jefferson/105.html. Madison was skeptical of this and other Jeffersonian proposals to rely on "We the People" as a basis for constitutional revisions beyond those governed by Article V. See The Federalist Nos. 47-51 (James Madison) (stating in The Federalist No. 49 that "a constitutional road to the people ought to be marked out and kept open, for certain great and extraordinary occasions," but that there were "insuperable objections against the proposed recurrence to the people"); Jack N. Rakove, The Super-Legality of the Constitution, or, a Federalist Critique of Bruce Ackerman's Neo-Federalism, 108 YALE L.J. 1931, 1954-58 (1999).

7 See, e.g., Lawrence Lessig, Out-Posting Post, in Robert C. Post, Citizens Divided: Campaign Finance Reform and the Constitution 97, 99-102, 230 n.19 (2014) (describing subtler forms of political corruption beyond quid pro quo bribery or extortion). There is no single generally accepted definition of, or term for, systemic political corruption. Wallis uses the term "systematic corruption." John Joseph Wallis, The Concept of Systematic Corruption in American History, in Corruption and Reform: Lessons 
in government. Peter H. Schuck performed a massive review of the literature reporting cost-benefit analyses of major government programs. He found that most programs fail to achieve their supporters' announced objectives. One possible explanation is that government usually is incompetent. Another is that supporters actually sought altogether different objectives than those announced. ${ }^{8}$ In the presence of systemic political corruption, one would ex-

From AmericA's EConomic History 23, 25 (Edward L. Glaeser \& Claudia Goldin eds., 2006) ("In polities plagued with systematic corruption, a group of politicians deliberately create rents by limiting entry into valuable economic activities ... [T] hese rents bind the interests of the recipients to the politicians who create them. The purpose is to build a coalition that can dominate government. Manipulating the economy for political ends is systematic corruption."). Lessig characterizes lawful corruption (with adverse welfare consequences) as "type 2" corruption. Lawrence Lessig, Republic, Lost: How Money Corrupts Congress-and a Plan to Stop It 228-33 (2011) [hereinafter Lessig, Republic] (characterizing "type 2" corruption as "dependency corruption," meaning that the "independence [of Congress] gets corrupted when a conflicting dependency develops," such that "the pattern of influence operating upon individuals within [Congress] draws them away from the influence intended."). (Type 1 corruption is, by Lessig's definition, unlawful.) Id. at 228 (“As I've described, the law regulating type 1 corruption permits Congress to block it (through bribery and illegal influence statutes), and to block contributions that raise a reasonable suspicion of it."). The term "institutional corruption" is common in the field of political philosophy and science. Seumas Miller, Corruption, Stan. Encyclopedia Phil., http://plato.stanford.edu/ archives/fall2005/entries/corruption (last visited Oct. 19, 2015). The Supreme Court has relied on a narrow definition - quid pro quo bribery-holding that corporate campaign expenditures on behalf of candidates is "not corruption or the appearance of corruption." Citizens United v. FEC, 558 U.S. 310, 357 (2010) (“"The absence of prearrangement and coordination of an expenditure with the candidate or his agent not only undermines the value of the expenditure to the candidate, but also alleviates the danger that expenditures will be given as a quid pro quo for improper commitments from the candidate."' (quoting Buckley v. Valeo, 424 U.S. 1, 47 (1976))). Wallis notes that political thinkers in the eighteenth century, including the Framers, used the same word, corruption, both for bribery and for systemic or institutional corruption. Wallis, supra, at 32-35, 38-43. The Framers may have emulated self-sacrificing patrician statesmen of the Roman Republic. See Gordon S. Wood, The Real Treason of Aaron Burr, 143 Proc. Amer. Phil. Soc. 280-295 (1999). Fukuyama provides a list of basic works on (mostly type 1) corruption. Fukuyama, supra note 5, at 82-83, 555 n.3. Kaiser and Teachout offer other recent perspectives. See generally Robert G. KaISER, So Damn Much Money: The Triumph of Lobbying and the Corrosion of American Government (2009) (documenting the rise of political lobbying in Congress through the story of one particularly successful lobbyist); Zephyr Teachout, Corruption in America: From Benjamin Franklin's Snuff Box to Citizens United (2014) (arguing that the Supreme Court's narrow conception of "corruption" in recent campaign finance decisions contradicts how American political thinkers have understood the term historically).

8 Peter H. Schuck, Why Government Fails So Often: And How It Can Do Better 4-6, 127-28 (2014). 
pect to find elite interests (and the politicians they support) disguising their true intent.

Systemic political corruption is widely acknowledged as a serious problem. Such corruption often impairs efficient production and allocation of goods and services, shrinking the pie. Corruption also often violates consensus principles of equity. Reduced economic efficiency shrinks (or fails to expand) aggregate well-being. ${ }^{9}$ Following John Rawls, consensus principles of equity require, at a minimum, avoiding policies that reduce the wellbeing of the least favored citizens. ${ }^{10}$ Corruption of this variety, rather than less common bribery or extortion, is the subject of this Essay. Bluntly, laws and regulations that reduce aggregate well-being or that reduce the wellbeing of the poor are either honest errors or the results of corrupt influence. In any case, they should be avoided or repealed.

Dominant interests that achieve and preserve advantages through corrupting influence each have narrow objectives involving a single political or policy issue. A particular interest may seek a tax concession, an import duty, a regulation increasing rivals' costs, or a national defense project for which they hope to supply goods and services. Each successful elite interest may affect aggregate well-being only slightly. Nevertheless, the process is ongoing and the aggregate effect is cumulative, and potentially very large.

Even a successful, dominant interest group must protect itself from rivals through continuing expenditures on lobbyists and campaign support. The process is dynamic - a banquet for politicians, lobbyists, and contributors that goes on 24/365, like a free buffet at a Las Vegas casino. In addition, even though each successful interest increases its share of the pie at the expense of other interests, the political process as a whole may result in every interest, strong and weak alike, ending up worse off in absolute terms. The resulting distribution of well-being may be one that even the winners find unattractive. ${ }^{11}$

Bribery of public officials is commonplace around the world and not uncommon in America. ${ }^{12}$ The cost of such corruption includes criminal theft or waste of tax revenues and other state resources. A greater cost in

9 Aggregate well-being as used here corresponds to the conceptions of general welfare and happiness, as used in the Preamble and Declaration, including well-being derived from the satisfaction of preferences for public goods, environmental amenities, and social justice. See infra note 109. I use the term "pie" as a metaphor for aggregate wellbeing.

10 See John Rawls, A Theory of Justice 302 (1971) ("Social and economic inequalities are to be arranged so that they are ... to the greatest benefit of the least advantaged, consistent with the just savings principle ...").

11 See Alan Feuer, Opinion, Billionaires to the Barricades, N.Y. Times (July 3, 2015), http://www.nytimes.com/2015/07/05/opinion/sunday/billionaires-to-the-barricades. $\mathrm{html}$ (discussing billionaires speaking out against growing income inequality).

12 See U. S. Department of Justice, Report to Congress on the Activities and operaTIONS OF the Public Integrity Section For 2014, available at http://www.justice.gov/ criminal/file/798261/. 
many countries is the reduction of private incentives to work, save and invest that stem from expectations of corrupt expropriation. However, many forms of corruption are lawful. Anything that causes a systemic, predictable divergence between the interest of the People and the interests of public officials, who are the agents of the People, gives rise to corruption, lawful though it may be. ${ }^{13}$

Corruption costs also arise from the adverse impact of hundreds of regulatory interventions that impair the efficiency of production and of markets. Many reflect agency compromises among warring elites, reached without regard for the cost imposed on the public. Major costs result from pervasive distortions in the tax system, ${ }^{14}$ and legislature-influenced federal procurement decisions. ${ }^{15}$

The more extensive the reach of government regulation of private economic activity, the greater the burden of corruption on the economy as a whole. Madison did not create a structure with this danger in mind. As a result, there is no institution in today's government that effectively restrains impositions on economic efficiency or distributional equity resulting from Congress's and agencies' responsiveness to well-organized interests-and their neglect of adverse effects on ill-organized interests. Within Washington, the process is taken for granted: it is business as usual, the way things are done.

Madison defended the new Constitution in The Federalist No.10 partly on the basis that a larger and more diverse republic would diffuse the power of interest groups ("factions") that, in a single state or region, might constitute an oppressive majority. The formation of a larger federal government might render such factions harmless by reducing them to minorities. Madison saw this mitigation of the effects of faction as far superior to attempting to regulate faction directly, for example, by restricting freedoms of speech, press, assembly and so on. The Federalist No. 10 foresees what I am calling systemic political corruption as inevitable, and claims that a strong but limited central government is preferable to individual state gov-

13 As discussed below, I treat political representatives as agents of the voters in a standard principal/agent framework. Suzanne Dovi described other and more complex characterizations. Suzanne Dovi, Political Representation, Stan. Encyclopedia Phil. (Jan. 2, 2006), http://plato.stanford.edu/entrie/political-representation (“[T]he concept of political representation has multiple and competing dimensions: our common understanding of political representation is one that contains different, and conflicting, conceptions of how political representatives should represent ...").

14 See Eric M. Zolt, Politics and Taxation: An Introduction, 67 TAx L. Rev. 453, 455 (2014).

15 Dean Neu, Jeff Everett \& Abu Shiraz. Rahaman, Preventing Corruption Within Government Procurement: Constructing the Disciplined and Ethical Subject, 28 CRITICAL PersP. ON ACCT. 49, 49-51 (2015). 
ernments because factional competition will be more robust in the larger arena. ${ }^{16}$

It is clear that the increased number and variety of competing factions, which the Federalists insisted would result from a stronger national government, have not forestalled corrupting factionalism. ${ }^{17}$ Factions are issueoriented; only the organized factions directly concerned affect policy on a given issue. They do not face pushback from other elite interests concerned with different issues. Perhaps local or regional factions do face greater difficulties in the federal system than they do in dealing with the states, but they have logrolling as a work-around. Moreover, a strong central government encourages the formation of national factions. In any event, the ratification of the Constitution has not prevented political corruption.

A republican or representative structure is a key feature of Madisonian democracy. This feature relies on an "agency" relationship between elected representatives and the voters. ${ }^{18}$ All types of political corruption reflect an agency failure: a government official sacrifices the public welfare to advance a personal or political agenda. In the Madisonian system, representatives are agents of the People acting in the People's interest; we rely on elections to produce trustworthy representatives who seek to advance constitutional objectives. ${ }^{19}$

"Agency" in economics refers to the relationship between a supplier of services and users of those services. Individuals and firms deal with sup-

16 By limited government, I mean limited in its jurisdiction or scope, measured, for example, by the percent of all economic and social interactions subject to government regulation.

17 Jeffrey M. Berry \& Clyde Wilcox, The Interest Group Society $3-4,187-90$ ( $5^{\text {th }}$ ed. 2009).

18 James E. Alt \& David D. Lassen, Political and Judicial Checks on Corruption: Evidence from American State Governments, 20 Econ. \& Pol. 33, 36 (2008); Robert J. Barro, The Control of Politicians: An Economic Model, 14 Puв. Cноге 19, 19 (1973) (describing a representational model "focus[ed] on the division of interests between the public and its political representatives," which arises "because the public officeholder is assumed to advance his own interests, and these interests do not coincide automatically with those of his constituents"); John Ferejohn, Incumbent Performance and Electoral Control, 50 Puв. Choice 5, 7-8 (1986).

19 This may include protecting the People from their own sometimes welfare-reducing impulses, which is the central point of representative democracy. It is beyond the scope of this Essay to consider the implications of the new behavioral economics. See, e.g., Raj Chetty, Behavioral Economics and Public Policy: A Pragmatic Perspective, 105 Am. Econ. Rev.: Papers \& Proc. 1, 1-3 (2015). But on the public choice incentives of policymakers, voters, and consumers, see Isaiah Berlin, Two Concepts of Liberty, in LiBERTY: INCORPORATING Four ESSAYS ON LiBERTY 166, 183-85 (Henry Hardy ed., 2002), discussing philosophical objections to certain behavioral interventions, and W. Kip Viscusi \& Ted Gayer, Behavioral Public Choice: The Behavioral Paradox of Government Policy, 38 Harv. J.L. \& Pub. Pol'y 973, 976-77 (2015), pointing out that public officials are subject to the same behavioral lapses as voters and consumers. 
pliers of goods and services when it is not efficient to produce their own. Although all suppliers can be thought of as agents, suppliers assume an important agency character when, due to information or skill asymmetry, supplier performance cannot easily be monitored by those who rely on the service. This condition may prevail even when users regularly consume the product or service if, for example, readily comparable alternatives do not exist, or some effects on happiness (or profit, in the case of firms) are delayed, occult, or situational. The production of law has this character.

Agency in this economic sense is fundamental to the division of labor that permits scarce resources to be employed more efficiently than would be the case in a world of autonomous individuals. Absent reliance on specialists, which is avoided when agents are seen as untrustworthy; humans would not have progressed much beyond hunting and gathering in small family groups. ${ }^{20}$ Cooperation among individuals, backed by social and cultural institutions, particularly law, is in constant tension with instinctive human self-interest.

In fact, there exists what may be a metaphor, an analogy, or perhaps even a deep biological connection between this agency tension and the tensions among the specialized cells of all multicellular livings things, including humans. Specialized cells sacrifice themselves to the benefit of the organism because doing so provides benefits from the division of labor and economies of scope, more than repaying the sacrifice. This achievement requires multiple dimensions of protection from cells that would cheat or "free ride" on the cooperative behavior of others, damaging the organism in the process. When these protections fail, the organism suffers from cancer. ${ }^{21}$ Similarly, when human agents with political power cheat, the social organism to which they belong is corrupted, injuring many or potentially all other members of society. ${ }^{22}$

20 The economic growth literature from the time of Adam Smith has laid great emphasis on the roles of economies of scale, the division of labor (specialization), and the sharing of knowledge and expertise amongst a growing population. See generally Charles I. Jones \& Paul M. Romer, The New Kaldor Facts: Ideas, Institutions, Population, and Human Capital, 2 Am. Econ. J.: Macroecon. 224 (2010).

21 C. Athena Aktipis et al., Cancer Across the Tree of Life: Cooperation and Cheating in Multicellularity, 370 Phil. Transactions Royal Soc’y London B: Biological Sci. 1, 1 (2015).

22 Competition and cooperation each play key roles in our culture. In many contexts, competition contributes to the general welfare, most often by selecting and promoting the fittest individuals or organizations for a particular role. However, competition can also reduce welfare by diverting resources to zero-sum struggles. In other contexts, cooperation is more effective in promoting welfare, often through economies of scale and specialization. Antisocial cooperation can reduce the gains available from competition, as in cartels, cabals, and oligarchies. In contrast to the generally prosocial effects of competition in economic markets, however, competition in other "markets" lack any a priori expectation of superiority over other decision-making methods. 
Legislators who advance the interests of those who, even tacitly, are necessary to reelection or career advancement are in essence soliciting and accepting bribes, even though the form of the exchange is lawful. It is an indictment of the system as a whole that modern public officials may have no choice. That is, support from one or more powerful interest usually is necessary to election and reelection. As Senator Robert Byrd explained on the Senate floor, " $[\mathrm{I}] \mathrm{t}$ is money! Money! Money! Not ideas, nor principles, but money that reigns supreme in American politics." 23

Although elections are competitions, they would not guarantee the performance of elected representatives even if the campaign finance system did not corrupt the contests. Voters are "rationally ignorant" of most aspects of their political agents' performance, especially non-salient legislation and administrative rule making. ${ }^{24}$ For some citizens voting participation stems in large part from impulse and emotion, motivated by a desire for self-validation. Indeed, many citizens who did not vote in recent elections (but share demographic characteristics with those who did) tend to report falsely in survey responses that they voted. ${ }^{25}$

Electioneering and voting are not exercises in public policy analysis. Voting certainly is not based, and these days could not possibly be based, on well-informed voter assessment of the contribution of incumbents either to local or national well-being. Relative advertising expenditures and simple name recognition strongly influence election outcomes, along with the attitudes predominant in each voter's immediate social network. A handful of high-salience policy issues dominate the media and influence debate. Changes in attitudes among political elites precede corresponding changes in the electorate. The process that produces elected officials is in many respects identical to the process that produces legislation-that is, a struggle among interest groups-and both are subject to political corruption by elite interests. The major virtue of elections is the absence of superior alternatives, just as Churchill suggested.

The existing Madisonian separation of powers and checks and balances are not effective safeguards against corruption because both the President and the judiciary are disinclined to oppose welfare-reducing legislation. ${ }^{26}$ Lack of line-item veto power and a need to maintain workable

23143 Cong. Rec. 3998 (1997) (statement of Sen. Byrd).

24 A great deal of empirical evidence supports the rational ignorance hypothesis presented in Anthony Downs, An Economic Theory of Democracy 258-59 (1957). See, e.g., Fernanda Leite Lopez De Leon \& Renata Rizzi, A Test for the Rational Ignorance Hypothesis: Evidence from a Natural Experiment in Brazil, 6 Am. Econ. J.: Econ. Pol'y 380, 381-82 (2014).

25 Stephen Ansolabehere \& Eitan Hersh, Validation: What Big Data Reveal About Survey Misreporting and the Real Electorate, 20 Pol. Analysis 437, 439-41 (2012).

26 See Alt \& Lassen, supra note 18, at 37-38. My thesis is not that high salience issues are likely to be decided in a way that increases welfare, but simply that high salience makes their resolution more democratic. In a Madisonian democracy we must grit our teeth and accept, at least temporarily, popular, welfare reducing majoritarian errors. 
relationships with legislators limits what the President can do. The courts typically avoid substantive review of welfare consequences of legislation and regulation, legal realism notwithstanding. ${ }^{27}$

Current practice relies on a corrupted institution (elections) and ineffective intramural branch rivalry to discipline a corrupted legislative system. This is rather like relying on the deterrent effect of the criminal law of arson as the sole remedy for house fires. Smoke alarms and firefighters are useful supplements to arson laws. A central theme of this Essay is that mechanisms to reduce the costs of political corruption should focus on examination of the welfare impact of legislation itself rather than on the political, or electoral processes, or motives that led to enactment. In addition to interdicting welfare- or equity-reducing laws directly, interdiction of welfare-reducing law will tend to reduce the incentive for interests and legislators to engage in political corruption.

Corruption is seldom addressed today from a Madisonian perspective. By "Madisonian" I mean the idea of using organizational structure to discipline political action-for example, dividing constitutional responsibilities among rivalrous institutions to achieve a "separation of powers" 28 or recognizing that sometimes controlling effects is better than regulating causative processes. ${ }^{29}$ Intramural rivalry among the branches reflects the trope common to the economic competition that disciplines markets, political competition among rival candidates, and sporting events.

We need not accept, however, low-salience outcomes favoring elite interest groups at the expense of the people. Such outcomes should not be accepted because they are not legitimatized by any expression of or appeal to the popular will.

27 The United States Court of Appeals for the D.C. Circuit, which hears many appeals from administrative agencies, has occasionally moved to discipline substantively corrupt regulatory policies. Such holdings are not routine, and generally rely at least in part on a procedural or other legal error by the agency. The courts are limited further by the Supreme Court's so-called Chevron doctrine which grants substantial deference to agencies' interpretations of enabling statutes. See Chevron U.S.A. Inc. v. Nat. Res. Def. Council, Inc., 467 U.S. 837, 865-66 (1984) ("When a challenge to an agency construction of a statutory provision ... really centers on the wisdom of the agency's policy, rather than whether it is a reasonable choice within a gap left open by Congress, the challenge must fail.").

28 See Charles de Secondat, Baron de Montesquieu, The Spirit of the Laws 157 (Anne M. Cohler et al. eds. \& trans., Cambridge Univ. Press 1989) (1748) ("When legislative power is united with executive power in a single body of the magistracy, there is no liberty, because one can fear that the same monarch or senate that makes tyrannical laws will execute them tyrannically. Nor is there liberty if the power of judging is not separate from legislative power and from executive power. If it were joined to the legislative power, the power over life and liberty of the citizens would be arbitrary, for the judge would be the legislator. If it were joined to executive power, the judge could have the force of an oppressor.").

29 The Federalist No. 10 (James Madison) ("The inference to which we are brought is that the causes of faction cannot be removed and that relief is only to be sought in the means of controlling its effects."). 
There has been a century-long expansion of central government jurisdiction in the United States. Changing political and policy preferences on the demand side and changing technologies, economic conditions, and political incentives on the supply side, may help to explain the expansion. In any event, I take the expansion as given in order to explore from an economic perspective the roots of political corruption and potential remedies for the modern proliferation of corrupt legislation and regulation. The objective is to explore possible Madisonian structural remedies as alternatives to, or at least as ways to postpone, a potentially radical Jeffersonian reboot.

Parts 2-6 of this Essay chiefly summarize existing literature and understanding. Part 3 describes the problem of lawful systemic or institutional political corruption in detail, explaining its role in reducing public wellbeing and distributive justice. My focus is on legislation that is non-salient and hence inaccessible to public scrutiny via the media or otherwise. Part 4 reviews the relevant objectives of government as described by the Framers of the Constitution. This step is antecedent to measuring the performance of Madisonian governance and a predicate to designing remedies for poor performance. Part 5 reviews a variety of commonly discussed remedies for systemic corruption. I conclude that most are ineffective or impracticable.

Part 6 explores the concept of quality control in organizations and specifically the role of "umpires" in sports and politics. I conclude that the addition of a quality-control umpire to the Madisonian branches would improve the performance of government by reducing the impact of lawful corruption both directly and through changed incentives. I also explore historical precedents and practical impediments. Part 7 provides some illustrative details of an umpire function, formulated as an Amendment, and Part 8 comments briefly on feasibility of the proposed approach to stemming welfare-reducing corruption.

\section{LAWFUL CORRUPTION}

Congress and much of the federal bureaucracy are now thoroughly corrupt in the sense that officials routinely service well-represented elites without regard to adverse effects on the well-being of the People..$^{30}$ The vast majority of legislation involves low-salience issues or low-salience riders to highsalience bills. Low-salience legislation is most likely to reflect corrupt influ-

30 "[P]olitical decay ... is evident in the capture of large parts of the U.S. government by well-organized interest groups. The old nineteenth-century problem ... [of political patronage] ... has been replaced today by a system of legalized gift exchange, in which politicians respond to organized interest groups that are collectively unrepresentative of the public as a whole." FukUYAMA, supra note 5, at 35-36. 
ence and to have adverse welfare or equity effects. Eric Lipton and Kevin Sack describe an illustrative instance of apparent low-salience corruption in the New York Times. Here is the lead:

Just two weeks after pleading guilty in a major federal fraud case, Amgen, the world's largest biotechnology firm, scored a largely unnoticed coup on Capitol Hill: Lawmakers inserted a paragraph into the "fiscal cliff" bill that did not mention the company by name but strongly favored one of its drugs. The language buried in Section 632 of the law delays a set of Medicare price restraints on a class of drugs that includes Sensipar, a lucrative Amgen pill used by kidney dialysis patients. ${ }^{31}$

Similarly, Igan and Mishra trace much of the blame for the 2008 financial collapse on political corruption in Washington. ${ }^{32}$ Lessig, ${ }^{33}$ Kaiser, ${ }^{34}$ and many others, offer numerous examples of such lawful corruption and their political and personal motivations. ${ }^{35}$

Proof that lawful corruption is rife in Washington relies largely on remembered personal experiences of former officials, lobbyists, and lawyers, and often takes the form of anecdotes. However, scholars using modern empirical methods have begun to trace such bad effects of corruption as trade barriers to their sources in corrupting interest group influences.

The most straightforward way to document political corruption is in connection with international trade barriers. Tariffs and quotas imposed on imported goods nearly always reduce welfare; they increase prices and restrict supply, reducing the well-being of both commercial customers and consumers. This is true whether or not foreign governments subsidize the imported goods. The beneficiaries of trade barriers are domestic suppliers of goods that face import competition. To illustrate, consider solar panels, which convert sunshine into clean electricity.

31 Eric Lipton \& Kevin Sack, Fiscal Footnote: Big Senate Gift to Drug Maker, N.Y. Times (Jan.19, 2013), http://www.nytimes.com/2013/01/20/us/medicare-pricing-delayis-political-win-for-amgen-drug-maker.html.

32 Deniz Igan \& Prachi Mishra, Wall Street, Capitol Hill and K Street: Political Influence and Financial Regulation, 57 J.L. \& Econ. 1063, 1082 (2014).

33 Lessig, RePuBlic, supra note 7, at 43-86.

34 KAISER, supra note 7, at 82-97.

35 Another line of empirical research attempts to use surveys of policy preferences in conjunction with data on incomes and policy outcomes to test various political theories of "who governs?" Martin Gilens \& Benjamin I. Page, Testing Theories of American Politics: Elites, Interest Groups, and Average Citizens, 12 Perspectives on Politics 564-581 (2014) provide one of the most recent and ambitious of these studies. The origins of political outcomes, however, likely depend on the nature of the matter at issue. High salience issues, for example, are more likely to invoke passionate and popular forces than the narrow, low salience issues that attract attention from special business, taxpayer and financial interests. 
The price of solar panels helps determine how much we can reduce air pollution emitted by conventional coal-fired power plants. In addition to contributing to the problem of global warming, conventional power plants have serious adverse effects on human health. Lower prices for solar panels means less air pollution, as consumers and businesses adopt solar power for their daytime needs. United States policy has been to encourage use of alternative (non-coal) power sources. The federal government and many states subsidize investments in solar power installations. So why would the federal government impose tariffs on solar panels imported from China, which has the world's largest and most efficient solar panel factories?

Late in 2014, the U.S. government imposed heavy tariffs on Chinese solar panels and their components. ${ }^{36}$ The tariffs, equivalent to sales taxes, range from about twenty-five to more than seventy percent, are intended to help domestic manufacturers compete with Chinese makers. The result is to increase prices paid by consumers and the profits made by U.S. manufacturers. U.S. producers are less efficient than suppliers in China and several other Asian countries. Higher prices for the panels make U.S. customers less likely to install solar panels, which reduces jobs related to panel installation and maintenance. Further, the tariffs make the environment unhealthier for U.S. citizens, increasing health care costs and reducing life expectancies. These effects are the same as those that would result from a criminal conspiracy among solar panel producers to fix prices. Executives and companies who did that would face jail time, fines, and expensive lawsuits. Fortunately for them, the U.S. government accomplished the same result, reducing the "general welfare." Consumers were not so lucky.

Trade barriers in general are unambiguous injuries to the general welfare; they result from political corruption. Domestic industries (and their labor unions) seek trade barriers by making campaign donations or independent expenditures to benefit Members of Congress. They also spend money to hire effective lobbyists, often former Members and senior committee staff. Protection of domestic industries is almost literally for sale. So-called "big data" and advanced econometric methods have documented these links. ${ }^{37}$ Consumers who pay the price increases and suffer the other

36 Diane Cardwell, U.S. Imposes Steep Tariffs on Chinese Solar Panels, N.Y. Times (Dec. 16, 2014), http://www.nytimes.com/2014/12/17/business/energy-environment/-us-imposes-steep-tariffs-on-chinese-solar-panels.html.

37 See, e.g., Stephen Ansolabehere, John M. de Figueiredo \& James M. Snyder, Jr., Why is There So Little Money in US Politics?, 17 J. Econ. Persp. 105, 126 (2003) (suggesting that the value of PAC contributions may be in buying access to lawmakers rather than in buying votes); Kishore Gawande \& Usree Bandyopadhyay, Is Protection for Sale? Evidence on the Grossman-Helpman Theory of Endogenous Protection, 82 Rev. ECON. \& STAT. 139, 150 (2000) ("The broad picture that emerges about the U.S. pattern of protection is that it is influenced by lobbying spending and lobbying competition, and that, hence, protection is 'sold."'); James Lake, Revisiting the Link Between PAC Contributions and Lobbying Expenditures, 37 Eur. J. PoL. ECon. 87, 96 (2015) (“[T]he sum of trade-related contributions and lobbying expenditures by, respectively, business 
effects of trade barriers have no effective voice in the political process that results from such systemic corruption.

Corruption has always been a camp follower of political power. Its modern form is imbalanced pluralism. Schattschneider called modern governance "pluralist" because legislative outcomes reflect the interplay of various interest groups. ${ }^{38}$ Pluralism involves political effort by such wellrepresented interests as regulated industries and professions (today, virtually all industries and professions) and passionate factions (the gun lobby, AARP, environmentalists). However, pluralism in practice omits unorganized and ill-represented interests such as citizens in their roles as consumers, nonunion workers, small investors, patients and so on. This lack of balance is corrupting because among the outcomes is a reduction in public welfare, at the expense of everyone, but especially absent interests. "If you are not at the table, you're on the menu." 39

Politics is useful because it addresses conflicts among contending interests without resort to costly and risky violence. Under benign political leadership, these conflicts can be resolved peacefully and often in a way that increases aggregate welfare. But especially now that the scope of government extends to every aspect of our daily lives, corruption has become a more serious threat to prosperity and political stability. The pluralist competition is imbalanced and so are its outcomes. Unless a Madisonian check or balance intervenes, welfare-reducing outcomes are likely to prevail. This undermines in the most fundamental way not merely the performance but also the legitimacy ${ }^{40}$ of representative democracy.

\section{Public choice theory}

The "public choice" literature in economics and political science explores the supply and demand for legislative action and related subjects. ${ }^{41}$ Like all

and labor groups reveals a statistically significant relationship between political money and voting on Free Trade Agreements ...").

38 See E. E. Schattschneider, The Semisovereign People: A Realist's View of DemocRACY IN AMERICA 34-35 (1960).

39 Kay Lehman Schlozman, Sidney Verba \& Henry E. Brady, The Unheavenly Chorus: Unequal Polttical Voice and the Broken Promise of American Democracy vi (2012) (citing a Washington truism).

40 "Democratic legitimation occurs when persons believe that the government is potentially responsive to their views ... Democratic legitimation therefore depends upon what people actually believe.” Robert C. Post, Citizens Divided: Campaign Finance Reform and the Constitution 49 (2014).

41 See, e.g., James M. Buchanan \& Gordon Tullock, The Calculus of Consent: Logical Foundations of a Constitutional Democracy 27-30 (1962); Downs, supra note 24, at 11-14; Mancur Olson, Jr., The Logic of Collective Action: Public Goods and the Theory of Groups 98-102 (1965); Mancur Olson, The Rise and Decline of Nations: Economic Growth, Stagflation, and Social Rigidities 50-53 (1982); James M. Buchanan, The Constitution of Economic Policy, 77 Am. Econ. Rev. 243, 243, 246-48 (1987); Dennis C. Mueller, Public Choice: A Survey, 14 J. Econ. Literature 395, 395- 
economic models-indeed, all scientific models, public choice (and its subfield of "constitutional economics") makes simplifying assumptions. The public choice literature typically assumes that voters and officials are "rational actors," and often emphasizes economic efficiency while sometimes neglecting income distribution. Critics decry normative conclusions that rely on such assumptions. ${ }^{42}$

Public choice models predict that Madisonian democracy will be corrupted through the influence of powerful interest groups on the electoral process, just as the Framers feared. Zywicki provides a succinct recent summary of the argument, including several real world examples of such political corruption. ${ }^{43}$ Public choice theories are attractive to those inclined to libertarian or objectivist views because the theories appear to suggest that "big government" reduces public welfare. Moreover, the logic of public choice undermines the legitimacy of Madisonian democracy because it traces ultimate political power to prevailing interest groups rather than to the people, given the influence of elites on election outcomes.

A common criticism of public choice theory is its neglect of "irrational" behavior. Attributes of honor, morality, and self-regard seem to contradict, or at least undermine, the narrowly defined concept of rationality that forms the basis for the theory. This criticism is vulnerable to empirical evidence that the political system in fact behaves as if its participants were rational actors in the sense relevant to public choice predictions. Such evidence is rife.

A less common criticism is that public choice theory generally neglects solutions other than reducing the size of government. That the extent of government will grow and continue to grow is a prediction of public choice theory itself, making it unlikely that even a heroic one-time rollback of government programs and regulations would create a permanent solution to the problem. A different and more effective solution is to change the structure of the political process that produces welfare losses as unintended byproducts of successful elite influence. It may not be practical to eliminate the political process in which interests compete for shares of the pie. But not all increases in elite shares necessarily come at the expense of the poor or have the effect of reducing the size of the pie. Public choice theory would serve us better if it focused on reforms that have the effect of restricting the

96 (1976); George J. Stigler, The Economic Theory of Regulation, 2 BeLl J. Econ. \& Mgmt. ScI. 3, 3-4 (1971).

42 See, e.g., Bruce Ackerman, Constitutional Economics/Constitutional Politics 415-16 (Yale Law Sch. Faculty Scholarship Series, Paper No. 124, 1999), available at http:// digitalcommons.law.yale.edu/fss_papers/124 ("In constitutional economics, the initial distribution of entitlements is treated as if it were sacrosanct ... To the contrary, it would be utterly wrong to allow the beneficiaries of injustice to veto any collective effort to stop them from enjoying the fruits of oppression.").

43 Todd Zywicki, Rent-Seeking, Crony Capitalism, and the Crony Constitution 17-25 (George Mason Univ. Legal Studies Res. Paper Series, Paper No. 15-08, 2015), available at http://www.law.gmu.edu/assets/files/publications/working_papers/LS1508.pdf. 
set of permitted redistributions to those that do not reduce the welfare of the least well off. This Essay offers an example of such a reform.

Progressive expansion

Significant expansion of central government jurisdictions and interventions in America began in the Progressive Era (roughly 1880-1920), partly in response to demands by organized interests and official desire to create and protect continuing streams of political support. The latter seems to have been an awakening of political entrepreneurship and innovation. National elites found it convenient to substitute federal for state-by-state political influence. Expansions also arose from popular-often populist—demands for protection against "unfair" behavior by others or from various perceived risks to well-being. It was in this era that the modern party system emerged in an ultimately futile attempt to increase electoral accountability. The Great Depression later cemented Americans' sense of reliance on big government.

Expansion of the federal jurisdiction produces "interventions"-most often, regulatory regimes. Interventions of course can mitigate market and other imperfections in human interactions and thus increase aggregate wellbeing. That is the point, for example, of criminal and civil justice systems.

Nevertheless, interventions intended to remedy even undisputed imperfections (air pollution, to take one example) are subject to corrupt design and implementation. Popular interventions often evolve to serve elite interests by distorting markets and behavior, usually at the expense of illorganized interests. The greater the number and reach of regulatory interventions, the greater the range of continuing opportunities for political corruption, in which one or more elite interest is serviced at the expense of other, less effective interests. Eventually these effects accumulate to slow or stop the improvement in well-being that results from economic growth and technological change.

When progress slows or stops, public discontent is inevitable. Americans have expectations of increasing prosperity. Such expectations may be out of reach in any case, but today widespread discussion of substantial and growing inequality ${ }^{44}$ reinforces discontent.

"The dramatic rise in U.S. wage inequality since the 1970s has been well documented." ${ }^{45}$ According to Joseph Stiglitz, "[r]eal U.S. wages have stagnated for decades. Adjusted for inflation, average hourly earnings of production and nonsupervisory employees have decreased some 30 percent since 1990. More dramatic, ... the aggregate share of labor excluding the top $1 \%$ compensation ... has slid from just under $80 \%$ to around $60 \% .{ }^{\prime 46}$

44 The connections among actual or perceived inequality, expectations, and political upheaval are complex. For a recent review and discussion, see Vladimir Gimpelson \& Daniel Treisman, Misperceiving Inequality 2-3 (Nat'l Bureau of Econ. Res., Working Paper No. 21174, 2015), available at http://www.nber.org/papers/w21174.

45 Jae Song et al., Firming Up Inequality 2 (Nat'l Bureau of Econ. Res., Working Paper No. 21199, 2015), available at http://www.nber.org/papers/w21199.

46 Joseph E. Stiglitz, New Theoretical Perspectives on the Distribution of Income and Wealth among Individuals: Part I. The Wealth Residual 2 n.6 (Nat'1 Bureau of Econ. 
While there are many explanations of growing inequality, corruption of political institutions is prominent among them.

There can hardly be a tavern in America where one can provoke an argument by claiming that all politicians are crooks. ${ }^{47}$ As the burden of corruption grows, those with poorly represented interests find themselves increasingly frustrated, powerless, open to demagoguery, and attracted to the

Res., Working Paper No. 21189, 2015) (emphasis added) (citations omitted), available at http://www.nber.org/papers/w21189.pdf.

47 See, e.g., Fukuyama, supra note 5, at 35, 455-548 (discussing "political decay," caused by institutional rigidity - the inability to reform institutions that produce bad outcomes - and repatrimonialization - the capture of large parts of government by interest groups); Richard L. Hasen, Lobbying, Rent-Seeking, and the Constitution, 64 STAN. L. Rev. 191, 196-97 (2012) (arguing that lax restrictions on lobbying activities not only contribute to corruption but also allow special interests to obtain economically inefficient and welfare-reducing legislation). Opinion polls have long shown that both politicians as a class and most political institutions, especially Congress, are widely disrespected. See, e.g., Post, supra note 40, 216 n.103 (citing polls); John R. Hiвbing \& Elizabeth Theiss-Morse, Congress as Public Enemy: Public Attitudes toward American Political Institutions 1-4 (1995) (discussing the public's disdain for Congress and other political institutions in the 1990s); John Hibbing, Images of Congress, in The Legislative Branch 461, 463-69 (Paul J. Quirk \& Sarah A. Binder eds., 2005) (charting the vacillations - and general decline - in the public's esteem of government institutions over the last century); Confidence in Institutions, GaLlup, http://www.gallup.com/poll/1597/confidence-institutions.aspx (last visited Oct. 21, 2015) (reporting that, in June 2015, Americans trusted Congress the least among fourteen other institutions, including the police, banks, and television news); Frank Newport, Congress Job Approval Drops to All-Time Low for 2013, Gallup (Dec. 10, 2013), http://www.gallup. com/poll/166196/congress-job-approval-drops-time-low-2013.aspx (reporting an annual average job approval rating for Congress of $14 \%$ for 2013, the lowest in Gallup's history); Frank Newport, Congressional Approval Sinks to Record Low, Gallup (Nov. 12., 2013), http://www.gallup.com/poll/165809/congressional-approval-sinks-recordlow.aspx (reporting Americans' approval of Congress at 9\% in November 2013); Trust in Government, GALLuP, http://www.gallup.com/poll/5392/trust-government.aspx (last visited Oct. 21, 2015) (showing that the public's trust in the federal government has steadily declined since 2001); Trust in Government Reaches Record Low, But Most Federal Agencies Are Viewed Favorably, Pew Res. CTR. (Oct. 18, 2013), http://www. people-press.org/2013/10/18/trust-in-government-nears-record-low-but-most-federalagencies-are-viewed-favorably (reporting that $30 \%$ of Americans described themselves as "angry" with the federal government, while another 55\% described themselves as "frustrated"). Quantification of corruption and its costs is challenging for obvious reasons. But see Mark Duggan \& Steven D. Levitt, Winning Isn't Everything: Corruption in Sumo Wrestling, 92 Am. Econ. Rev. 1594, 1595-96 (2002) (conducting empirical study of corruption in sumo matches); Raymond Fisman, Estimating the Value of Political Connections, 91 Am. Econ. Rev. 1095, 1095-96 (2001) (developing quantitative index to measure firms' political connectedness in Indonesia, and finding that "a large percentage of a well-connected firm's value may be derived from political connections). 
attentions of opportunistic politicians at all extremes. Politicians that are more centrist often jump on the resulting bandwagon. This process tends to produce additional interventions, each of which presents a continuing stream of opportunities for officials to reward elites within programs characterized and even intended as remedial. The process is a negative-sum game that, unchecked, may eventually have an unhappy Jeffersonian ending. ${ }^{48}$

The Framers of the American Constitution were familiar with corruption, which permeated the $18^{\text {th }}$ century British parliament and the monarchy. Partly in response, the Framers designed a small federal government with limited powers, which necessarily operated with the available technologies of 1787 . That design is no longer adequate to constrain corruption of public officials or to make their incentives reasonably compatible with the interests of the People. What has changed is not necessarily the inclination of a typical elected official to seek private objectives at the expense of aggregate well-being. Instead, that inclination is now presented with a much wider set of opportunities, often embedded in politically legitimate responses to public needs or demands. Specifically, ongoing regulation of any economic or social activity by an administrative bureaucracy creates a fulcrum of interest group leverage. Leverage is exercised directly on the political appointees that head the agency and on career bureaucrats and is traceable in most cases to members of congressional committees. ${ }^{49}$

Before discussing remedies for these problems we need to agree on the purposes of government and to understand James Madison's constitutional design and its objectives. In considering remedies for systemic corruption our focus must be on the performance of constitutional structures in achieving the Framers' (and the People's) key objectives, which remain largely uncontroversial.

48 Violent revolution in America may be a long shot, but not for lack of impassioned despair at political corruption from both ends of the political spectrum. Compare Chris Hedges, Wages of RebelLion 1 (2015) (arguing that "[w]e live in a revolutionary moment," citing the Arab Spring, the Occupy Wall Street protests, and other protests around the globe in the early 2010s), with Charles Murray, By the People: Rebuilding Liberty Without Permission xiii (2015) (arguing that "we are at the end of the American project as the founders intended it," but that "opportunities are opening for preserving the best qualities of the American project in a new incarnation").

49 The delegation of legislative, judicial and executive power to administrative units established a linkage between individual members of Congress and administrative agencies, creating not only an immense expansion of opportunities for elite interests to influence policy, but also undermining the Madisonian separation of powers. See Neomi Rao, Administrative Collusion: How Delegation Diminishes the Collective Congress. 90 N. Y. Univ. L. Rev. No. 5. (2015) 101, at 140-45. 


\section{The Framers’ objectives}

The delegates to the 1787 constitutional convention in Philadelphia shared overlapping views of the proper role of government. The Framers' views were derived largely from John Locke and other Enlightenment philosophers, the delegates' own educations in the Greek and Roman classics, their observations of British institutions, and their experience with colonial governance. Many had participated in drafting new postcolonial constitutions in their home states. Some were practical men who appreciated as constraints the economic and political interests of prospective ratifiers in the several states. ${ }^{50}$ We have indications of their intent, in the prevailing Enlightenment climate of opinion, but most clearly and famously in the Declaration of Independence, the Federalist Papers, and the Constitution's Preamble.

We the People of the United States, in Order to form a more perfect Union, establish Justice, insure domestic Tranquility, provide for the common defense, promote the general Welfare, and secure the Blessings of Liberty to ourselves and our posterity, do ordain and establish this Constitution for the United States of America. ${ }^{51}$

Jefferson's politically popular and pithy statement of the proper role of government, adopted and published a decade earlier by many of the same men who returned to Philadelphia in 1787, offers another excellent guide to the Founders' intent.

We hold these truths to be self-evident, that all men are created equal, that they are endowed by their Creator with certain unalienable Rights, that among these are Life, Liberty and the pursuit of Happiness. - That to secure these rights, Governments are instituted among Men, deriving their just powers from the consent of the governed, - That whenever any Form of Government becomes destructive of these ends, it is the Right of the People to alter or to abolish it, and to institute new Government, laying its foundation on such principles and organizing its powers in such form, as to them shall seem most likely to effect their Safety and Happiness. ${ }^{52}$

50 See generally Pauline Maier, Ratification: The People Debate the Constitution, 1787-1788 (2010) (describing in some detail the process and the politics of ratification).

51 U.S. Const. pmbl. The Supreme Court has held that "Although that Preamble indicates the general purposes for which the people ordained and established the Constitution, it has never been regarded as the source of any substantive power conferred on the Government of the United States or on any of its Departments.” Jacobson v. Massachusetts, 197 U.S. 11, 22 (1905).

52 The Declaration of Independence para. 2 (U.S. 1776) (emphasis added). 
Key ideas in the Declaration of Independence and the Preamble still appear in the speeches of modern politicians, but they have become ritualistic. It is clear enough how Madison's Constitution served the ends of life and liberty by creating specific personal rights against the government. ${ }^{53}$ More important for present purposes, the Preamble says, in different words, the same thing as the quoted paragraph from the Declaration, that the general welfare of the People-their capacity to achieve happiness-should be a primary objective of government, no less fundamental than protection of life and liberty.

The Framers accepted the necessity of government itself as protection from Hobbesian dangers and as provider of essential collective services, such as national defense and justice, and for the peaceful resolution of conflicts. While these functions advance the purposes of government, the Framers also saw two related threats-those of tyranny and of corruption. The larger and more powerful the government, and the broader its scope, the greater the extent or threat of tyranny. Moreover, given the inherent selfinterest of public officials-even if only for their own careers-government that is more extensive implies a greater burden of corruption.

The Federalists' Constitution relies on limited government (now abandoned) and on elections to control corruption. The Framers were well aware of the potential shortcomings of voters and elections, but saw no superior alternative. Indeed, it was Federalist doctrine that the People themselves were the only legitimate source of political power. The Constitution produced by the Philadelphia Convention of 1787 relied on ratification by the People for its own legitimacy. ${ }^{54}$

This objective helps explain Madison's creation of a central government structure that permits or even encourages "gridlock." ${ }_{55}$ In the absence of near unanimity among the interests supporting the branches, each with

53 Much of the Constitution consists of "negative rights." These are limitations on what the government may do to individuals. These rights also create a remedy-a positive right — enabling the individual to call on the judiciary, the legislature, or the People to restrain government abuse of individual rights. Similarly, a traditional liberty can be seen as an entitlement and an entitlement can often be viewed as a liberty. For example, freedom from expropriation of property, a traditional liberty with roots in Magna Carta, entitles citizens to state enforcement of a right. Health care in old age (Medicare) is an entitlement that confers liberty from a particular category of suffering and dependency on others.

54 Rakove, supra note 6, at 1938. Political legitimacy has more than one definition, but it most commonly refers to what people believe. See Max Weber, The Theory of Social and Economic Organization 328 (A. M. Henderson trans., Talcott Parsons ed. \& trans., 1947) (discussing three types of legitimate authority). For a broader discussion, see Fabienne Peter, Political Legitimacy, Stan. Encyclopedia Phil. (Apr. 29, 2010), http:// plato.stanford.edu/entries/legitimacy.

55 Madisonian gridlock results from intramural rivalry among the branches. Modern gridlock is, admittedly, in large part a product of partisan extremism. Another variety of gridlock results from the Senate's tradition permitting a single Senator to hold up a bill 
veto power over the others, the federal government would be prevented from acting quickly or easily. ${ }^{56}$ The Framers would also have taken as given the technologies of their times, which themselves limited the roles of central government in a vast and growing nation. Madison could hardly have foreseen or imagined the nineteenth century changes that eventually made unlimited central government inevitable, among them national markets, mass production, the limited liability corporation, and revolutions in communication and transportation. Most important, by the twentieth century, for many citizens government had become the natural panacea for all social and economic discontents and the favored vehicle for all social aspirations.

Madison designed federal government structure to minimize the potential cost, in corruption and tyranny, of supplying what were in 1787 considered the essential services of government. He also designed the Constitution to appeal to a majority of ratifiers. By the early twentieth century the Madisonian structure had come under enormous strain. The ratifiers of 1788 were no longer representative of the popular will. Agricultural, industrial, labor, and other easily organized supply-side interests began to demand added central government protections and compensations in adjusting to the new age of mass production and mass media. By the time of the New Deal, such demands had been greatly magnified.

Simultaneously, the federal government became freer to respond to demands for political solutions to economic discontents. Big business had pioneered the development of scientific management and large organizational hierarchies. A professional and reformed civil service, freed of patronage appointments by early in the twentieth century, faster and cheaper communication and transportation, and national media enabled Congress to offer solutions to the problems of organized interests who could produce votes, directly or indirectly. Simply put, central government services could now expand to meet the demand. As the Supreme Court has noted, the federal government today, a century after the Progressive movement, "wields vast power and touches almost every aspect of daily life ..." 57

Broadly speaking, the expansion of government that began in the Progressive era has been associated not with provision of more effective or extensive liberties, but with the creation and administration of new entitlements. Both liberties and entitlements require administration, as do taxation and procurement. Administration of each of these functions unavoidably implies policies, rules, regulations, and adjudications that directly or indirectly marshal and reallocate resources within the private economy. Administration, whether assigned to independent or executive branch agen-

or confirmation without explanation. The House has traditions and rules with similar effect. Single-member holds can facilitate lawful corruption.

56 The Article III courts did not become a full-fledged Madisonian branch until the Supreme Court made clear that it claimed the right of judicial review of legislation in Marbury v. Madison, 5 U.S. 137, 177 (1803).

57 Free Enter. Fund v. Pub. Co. Accounting Oversight Bd., 561 U.S. 477, 499 (2010). 
cies, entails the exercise of discretion. Both agency officials and members of congressional appropriations and oversight committees must choose among options that create and destroy income and wealth.

Participants in the economy and other interests today therefore have enormous incentives and opportunities to influence government policy. Well-funded interest groups wield much of their leverage by influencing policy options selected. Their objectives, broadly, are to advance their own agendas without regard to the impact on other interests or on the economy as a whole. The public choice term for this is "rent seeking." 58 Rent seeking by elite interests is nearly by definition regressively redistributive and reduces aggregate welfare. The name itself derives from the monopoly rents (profits) gained by Stuart, Tudor, and earlier royal favorites who were granted such concessions as the right to collect customs duties at a British port of entry. Elites succeed today by providing elected officials with financial and other support, by foregoing such aid to rival candidates, hiring appointed officials after they leave office, and providing all officials with substantive resources crucial to the legislative or rule-making process. In consequence, of course, organized interests threatened by rivals are obliged to defend themselves in like fashion. The goals of elite interests often are most effectively pursued by inducing public officials to neglect their obligations to the People as a whole. Public officials, meanwhile, can advance their careers as elective officials or appointed regulators, or later as lobbyists, by servicing these interests. ${ }^{59}$ Elected legislators, in fact, may have little choice, even if they hope merely to remain in office, but to promote interests that will support, or at least not oppose, their reelection. In contrast to preDepression practice, the Supreme Court no longer resists these expansions of federal jurisdiction and intervention.

The Framers likely perceived the consequences of corruption in a small and limited government as a tolerable cost of doing business. To put it the other way around, limited government meant limited opportunities for corruption. Further, many potentially effective anticorruption measures

58 Anne O. Krueger, The Political Economy of the Rent-Seeking Society, 64 Am. Econ. Rev. 291, 302 (1974); see also Gordon Tullock, The Welfare Costs of Tariffs, Monopolies, and Theft, 5 W. Econ. J. 224, 228, 231---32 (1967) (examining the welfare costs of rent-seeking activities, such as tariffs and monopolies, and the additional costs associated with political lobbying).

59 According to Professor Reich, "In the 1970s only 3 percent of retiring members of Congress went on to become Washington lobbyists. Now, half of all retiring senators and 42 percent of retiring representatives become lobbyists." Robert Reich, Opinion, Legal Scandals and "Anticipatory Bribery" Abound, SFGate (June 12, 2015, 3:07 PM), http://www.sfgate.com/opinion/reich/article/Legal-scandals-and-anticipatorybribery-6320025.php. See also Jordi Blanes i Vidal, Mirko Draca \& Christian FonsRosen, Revolving Door Lobbyists, 102 Am. Econ. Rev. 3731, 3731 (2012) (describing the phenomenon of "revolving door lobbyists"); Timothy M LaPira and Herschel F Thomas III, Revolving Door Lobbyists and Interest Representation, 3 INTEREST GrouPS \& ADVOCACY 4-29 (2014). 
conflict with constitutional freedoms; Citizens United makes a good example: to reduce corruption in elections we must invade freedom of speech. Nevertheless, what may have seemed a tolerable cost in 1787 , relative to aggregate economic activity, has today been greatly inflated by the expanded role of government, and more so as the freedom to petition Congress has become the focus of a large professional class.

It is instructive to consider how an effective constraint on political corruption could fit into the Madisonian structural framework, lacking limited government. The more urgent point is that, if we do not find a less dangerous solution to the corrupt consequences of modern demands for an unlimited administrative state, we may be faced with the messy Jeffersonian default:

[I]t is the Right of the People to alter or to abolish [government], and to institute new Government, laying its foundation on such principles and organizing its powers in such form, as to them shall seem most likely to effect their Safety and Happiness. ${ }^{60}$

\section{Potential Remedies for political CORRuption}

It is useful to begin with proposals to control political corruption that are not especially Madisonian. These are mostly well known and often advocated, but unsatisfactory in various respects.

\section{A. BRoAden the REACH OF CRIMINAL LAW}

It is tempting to suggest that authors of welfare-reducing legislation, and perhaps even those who vote for such laws, should face criminal penalties. However, the criminal law would be of little help in controlling currently lawful corruption. ${ }^{61}$ The behavior of legislators is often difficult to categorize. At one extreme, it may be unlawful, for example, frank bribery or extortion. ${ }^{62}$ At another extreme, it may be unambiguously virtuousbeneficial to constituents or citizens generally and neutral or adverse to the legislator's personal interest. Legislative behavior commonly reflects

60 The Declaration of IndePendence 92 (U.S. 1776).

${ }_{61}$ See Post, supra note 40 at 57 ("And unlike straight cash-for-votes transactions, such corruption is neither easily detected nor practical to criminalize." (quoting McCutcheon v. FEC, 540 U.S. 93, 153 (2003), overruled on other grounds by Citizens United v. FEC, 558 U.S. 310 (2010)).

62 Alex Stein, Corrupt Intentions: Bribery, Unlawful Gratuity, and Honest-Services Fraud, 75 L. \& Contemp. Probs. 61, 6162 (2012) (describing elements of bribery and related offenses and reviewing cases). 
mixed motives and complex interactions with other legislators as well as imperfect information about the effects of the law itself. For this reason, constraints on legislative behavior intended to deter corruption can easily generate false positive or negative errors and adverse welfare consequences. Classifying currently lawful influences and their consequences as crimes is also inadvisable because of the difficulty of proving intent.

\section{B. CAMPAign FinANCE REFORM}

There is a widespread appreciation that campaign contributions, in cash or kind, are a way to buy influence with elected officials or, when offered to a candidate's opponent, a way to punish officials who oppose the contributor's aims. Most officials will admit that large contributions buy accesssignificant contributors typically can easily communicate their views to an elected official, and those views are likely to receive respect. Even legislators not up for reelection benefit from contributions that flow through to party coffers or other candidates because these contributions buy advancement within the party leadership hierarchy. Membership of legislators on relevant appropriation and oversight committees creates channels of influence to executive and agency officials. Access also accompanies the "revolving door" of congressional staff alumni appointed to regulatory commissions and executive agency positions.

This exchange-money for access-is very much like a bribe. Of course, the official generally does not explicitly agree to vote or otherwise act in the donor's interest. The agreement is tacit. If the official would prefer to act in a way that is at odds with the contributor's interests, she will take pains to explain why she cannot support the donor's position. She will strive to find concessions, compromises, or perhaps side payments on unrelated matters. This interaction is very much like explicit bargaining over the price of (continued) political support. However, because the interaction between officials and supporters is a "repeated game," there is no need for explicit agreement. The large special interest contributor, unlike the typical voter, is able to monitor the representative's performance of the tacit agreement. The contributor can punish a reneging official by withdrawing support or by supporting the official's rivals. Threats to do so are highly credible.

Campaign finance is such an obvious source of corruption that many popular reform proposals focus on limiting contributions from special interests. Examples include the reforms associated with Professor Larry Lessig's brief 2015 campaign for the Democratic presidential nomination and the related "Honest Election Seattle" voucher reforms approved by voters on November 3, 2015.63 In Washington, Congress has enacted a variety of limits and reporting requirements on campaign contributions.

${ }_{63}$ Bob Young, 'Democracy vouchers' win in Seattle; first in country. SeatTle Times, Nov. 3, 2015. http://www.seattletimes.com/news/politicsdemocracy-vouchers/. 
Unfortunately, reforms aimed at campaign finance are unlikely to be effective in limiting lawful corruption. First, the reforms enacted so far have been easily evaded by parties, donors and candidates. The most effective work around is the "independent" organizer of campaign support and expenditure. So long as the independent supporter (individual or corporation) does not coordinate directly with the candidate, the First Amendment provides complete protection for unlimited expenditures.

Second, campaign contributions and independent expenditures, while important, are less significant than the relationships between lobbyists and officials. Lobbyists, often alumni of Congress and congressional staffs, are effective because they earn, or have earned, the gratitude and trust of officials. Officials in need of data or arguments in support of their positions often turn to lobbyists for support, including on matters unrelated to a lobbyist's immediate interests. ${ }^{64}$ Sometimes committees or Members of Congress hire lobbyists to serve in important staff positions related to the very issues about which they lobbied. Private sector expenditures on lobbying are many times greater than campaign contributions. ${ }^{65}$ The relationships between helpful lobbyists and officials generate feelings of gratitude that make officials reluctant to decline support for the lobbyist's clients. ${ }^{66}$

On the other hand, the logic of representative government relies on representatives having accurate information about the problems and preferences of the electorate. Direct communication between citizens, their or-

${ }^{64}$ Nicholas W. Allard, Lobbying is an Honorable Profession: The Right to Petition and the Competition to be Right, 19 Stan. L. \& Pol'y Rev. 23, 42 - 44 (2008).

65 The Center for Responsive Politics compiles data on contributions and lobbying expenditures based on reports mandated by federal laws and Congressional rules. See Center for Responsive Politics, www.opensecrets.org (last visited Oct. 23, 2015). There is general agreement that lobbying expenditures greatly exceed expenditures on campaign donations. See Mirko Draca, Institutional Corruption? The Revolving Door in American and British Politics 8 fig.3 (SMF-CAGE Glob. Perspectives Series, Paper No. 1 2014), available at http://www.smf.co.uk/wp-content/uploads/2014/10/ Social-Market-FoundationInstitutional-Corruption-the-revolving-door-in-Americanand-British-politics.pdf. The data themselves, however, are often of poor quality and almost certainly understate both sorts of expenditures, especially lobbying. Some data include and other data exclude state and local lobbying, but in principle all data exclude legal services provided by the same firms and individuals that lobby. The incentive of reporting firms is to minimize reported lobbying expenditures; legal expenses are not disclosed. See Austin C. Clemens, All Politics is Local, but Lobbying Is Federal and Local: The Validity of LDA Data, 16 Bus. \& PoL. 267, 268 (2014). Many scholars have mined these and related election data. Lake, supra note 37, at 88-96 (summarizing recent findings). The current view, according to Lake, is that interest groups make both lobbying expenditures and campaign contributions, seeking to influence policy outcomes on specific issues. Id. at 96.

66 Even small favors can generate powerful feelings of gratitude. Ulrike Malmendier \& Klaus Schmidt, You Owe Me 31-32 (Nat'l Bureau of Econ. Res., Working Paper No.18543, 2012). 
ganizations, and representatives is an important means of acquiring such information. Indeed, the Petition Clause of the First Amendment protects such communication. Yet such protected communications, accompanied by support of the candidate for election or re-election, appears to have the same consequence as a cash bribe.

The Supreme Court faced one facet of the problem in Citizens United, which focused on "independent" campaign expenditures in support of a candidate, as opposed to contributions made directly to a candidate. The Court had previously upheld most statutory limitations on direct contributions as well as reporting requirements. In Citizens United, the Court had to balance the public's interest in clean politics against the First Amendment freedoms to speak and to petition Congress.

The Court's exceedingly narrow definition of corruption as common bribery informed its decision. The Court evaded the real question posed by corporate expenditure in the context of systemic faction-based political corruption. ${ }^{67}$ Most constitutional scholars object to the Court's definition of corruption, or at least to the Court's originalist argument for the definition. Nevertheless, it is difficult to fault the Court for its choice to promote free expression at the necessary expense of corruption-corruption that, in any case, would not be much reduced by regulation of political spending.

Notoriously, candidates and contributors have evaded or avoided a succession of attempts to limit direct campaign contributions. There is usually a lawful way around any regulatory constraint, albeit generally at some cost. Given that the very politicians targeted by the regulations draft the regulations, any other result would be surprising. ${ }^{68}$

Campaign finance reform, even if it "succeeded," would not solve the problem posed by political representatives whose incentives are at odds with the interests of the People. Well-organized and well-financed interests would still be able to influence officials. Given the Framers' choice to promote access to legislators and their reliance on elections, combined with the inherent ambiguity of political motivation, campaign finance reform appears futile as a remedy for systemic corruption.

${ }_{67}$ See Post, supra note 40, at 58.

68 In recent developments, the Supreme Court struck down limits on aggregate individual contributions, McCutcheon v. FEC, 572 U.S. 1434, 1462 (2014), and Congress passed legislation increasing permissible contribution caps on contributions to parties. See, Eliza Newlin Carney, Parties Poised to Exploit Broad New Rules, Roll Call (Jan. 6, 2015, 12:00 PM), http://blogs.rollcall.com/beltway-insiders/parties-poised-to-exploit-broadnew-rules; Press release, Fred Werthheimer, Statement on Reid-McConnell "Bipartisan" Deal to Eviscerate Anti-Corruption Campaign Finance Laws (Dec. 10, 2014), available at http://www.democracy21.org/legislative-action/press-releases-legislative-action/fredwertheimer-statement-on-reid-mcconnell-bipartisan-deal-to-eviscerate-anti-corruptioncampaign-finance-laws. Presidential candidates were also accused of "skirting" federal election rules. See Eliza Newlin Carney, Presidential Hopefuls Skirt FEC Rules, Roll Call (Feb. 26, 2015, 3:00 PM), http://blogs.rollcall.com/beltway-insiders/presidentialhopefuls-skirt-fec-rules-rules-of-the-game. 


\section{Tighten Regulation of LOBbying}

Although statutes require Washington lobbyists to register, identify clients, and report contributions, there is little chance that such regulation has or will reduce corrupted legislation. After all, the First Amendment encourages lobbying. If lobbying were effectively ended, isolated elected officials would have less information about legitimate (welfare-enhancing) legislation and legislative debate would be less well informed. Moreover, restrictions on access by current lobbyists do not address the underlying problem, which is that important unorganized interests lack the means to hire professional lobbyists. In other words, lobbying is not the problem; the problem is imbalanced lobbying. It is unclear, however, how to define or achieve "balanced" lobbying. Regulation cannot make lobbying more balanced. Once again, as with campaign finance, it appears futile to rely on reforms aimed at decreasing the effectiveness or imbalances of lobbying as a means to improve legislative outcomes.

\section{Congressional REFORM}

Congressional reform could be a path to mitigate corrupt legislation. On several occasions, Congress has found the means to impose discipline upon itself and its members. For example, a legislative branch agency, the Congressional Budget Office (CBO), "scores" proposed legislation with respect to impact on budget deficits. Members of Congress generally accept the result as an authoritative bipartisan constraint on deficit spending. Another reform permits a suspension of normal procedure for trade bills, the so-called "fasttrack" for ratification of trade agreements. Similarly, the Base Closing Commission (BCC) reviews proposed retirements of domestic military facilities. The BCC produces a list of recommended closings, and the Congress votes on the package as a whole, rather than on individual closings.

Finally, both houses of Congress have rules restricting non germane amendments to bills on the floor and restrictions on so-called "earmarked" bills proposed by individual legislators. Nevertheless, these rules are not effective. Corrupt bills often become law by riding the coattails of "vetoproof" spending bills in the form of non-germane amendments or line items inserted in committee or in conference.

The problem with many, perhaps all, congressional reforms is that Congress cannot bind itself to follow its own rules next week, much less bind future Congresses. The most recent law on a given matter always trumps preceding laws. Moreover, majority party leaders can decide with impunity to ignore congressional rules simply by suspending them. No branch, court, or police agency can intervene; for example, party leaders are in continuing negotiations with members of their caucuses to gain support for legislation that advances party objectives. A crucial bargaining tool in the negotiations is the leaders' ability to include bills favored by particular members (and the interests supporting that member) in the portfolio of must-pass party legislation. This mechanism is necessary to party discipline and congressional leaders are unlikely to let procedural rules prevent its use. 


\section{E. The Westminster SYSTEM}

One of the remarkable features of Madisonian democracy is its competing independent but inter-dependent branches. Most democracies use a parliamentary system. In the Westminster system, the prime minister is both head of government and the leader of the majority party or coalition in the legislature. The prime minister's party controls the legislative agenda and executes the resulting law, directing a permanent professional civil service. Gridlock normally is absent from such a system, or has been since the monarch and the House of Lords have been effectively taken out of the picture.

When it comes to the role of well-organized interests and lobbyists, the situation in Britain and other parliamentary democracies is no different from the United States. ${ }^{69}$ Corrupt influences, corrupt practices, and important illorganized interests exist everywhere. Party leaders still need to negotiate with members of parliament, and both candidates and parties crave financial and career support from interest groups.

The chief relevant difference between Washington and Westminster is that in Britain there is no ambiguity about assigning responsibility for policy and performance to the current majority party, which may give voters a clearer basis for their decisions in the next parliamentary election. While a parliamentary system might alleviate the frustrations associated with Washington "gridlock," it is far from clear that it would significantly reduce corrupt laws or corrupt law enforcement by administrative agencies in non-salient matters. The party in power and sometimes the minority, in general, would retain incentives and numerous opportunities to cater to elite interests without regard to the public welfare. Finally, pursuit of a parliamentary structure in the United States would almost certainly require a massive constitutional amendment or a constitutional convention under Article V, perhaps a dangerous undertaking. ${ }^{70}$

69 Draca, supra note 65, at 13-14.

70 Article V offers two methods: congressional legislation ratified by a supermajority of the states, or a constitutional convention, for which the only precedent is the Philadelphia Convention of 1787. Although beyond the scope of this Essay, constitutional reform in the U.S. is thought to be hampered by the grave difficulty of amending the Constitution. But see Tom Ginsberg \& James Melton, Does the Constitutional Amendment Rule Matter at All? Amendment Cultures and the Challenges of Measuring Amendment Difficulty, (Coase-Sandor Inst. for Law \& Econ., Working Paper No. 682, 2014). available at $\mathrm{http} / / /$ chicagounbound.uchicago.edu/law_and_economics_wp (conducting empirical analysis and arguing that attitudes about amending constitutions, or "amendment culture," is a better predictor of how easily and often a constitution may be amended than the number and rigidity of formal legal barriers to amendment). As noted above, tacit amendment by the Supreme Court is far more common than the formal routes. 


\section{F. THE PRESIDENTIAL VETO AND THE UNITARY EXECUTIVE}

Why does the President not simply veto corrupt welfare-reducing legislation? Most Presidents have wielded their veto power sparingly. This is not difficult to understand. First, the Supreme Court has denied the President line item veto power. ${ }^{71}$ That enables Congress to package corrupt legislation in bills that the President cannot veto without endangering his own agenda or even the Republic. ${ }^{72}$ Further, Presidents are in much the same position as congressional party leaders-they are in continuing negotiations, a repeated game with Congress, its leaders, and its members as they seek to advance their own legislative agendas. If they adopted a policy of vetoing corrupt legislation, that might forestall the passage of such legislation but only at the price of depriving themselves of a key negotiating tool. In addition, Presidents are themselves often beholden to the same interest groups that influence Congress. Even Presidents who cannot succeed have loyalties to aides, appointees, and nowadays, family members with political ambitions requiring elite interest support.

A realistic appreciation of the political constraints facing any President also undermines a proposed reform aimed at malfeasance in the federal administrative bureaucracy, which includes cabinet departments as well as independent agencies. Justice Elena Kagan, then a Harvard law professor, discusses the idea in a 2001 law review article. ${ }^{73}$

The premise of the unitary executive (which Kagan calls Presidential Administration) is that most so-called "independent agencies" such as the Federal Communications Commission (FCC) or the Securities and Exchange Commission (SEC) are in thrall to the interests they regulate, producing rules and regulations harmful to public well-being. The Ford and Carter administrations abolished or greatly pared back many regulatory agencies. This was due in part to activism by the Senate Judiciary Commit-

71 Clinton v. City of New York, 524 U.S. 417, 448 - 49 (1998).

72 The line item veto is politically as well as constitutionally controversial, implicating the separation of powers as well as the legislative process. One point of departure is to note that the governors of most states enjoy line item veto power, in varying forms, and that the Supreme Court has long enjoyed and exercised a line item veto in reviewing the constitutionality of federal legislation. Whatever theoretical changes in the relative powers of the branches or in legislative logrolling may result from line item veto authority, it does not seem to have engendered cataclysmic consequences. See John R. Carter \& David Schap, Line-Item Veto: Where Is Thy Sting?, 4 J. Econ. Persp. 103, 112 (1990) (reviewing empirical studies and finding that they "provide little or no evidence that total spending, budget outcomes, or executive power are substantially affected in general by item-veto authority"); Philip G. Joyce \& Robert D. Reischauer, The Federal Line-Item Veto: What Is It and What Will It Do?, 57 Pub. Admin. Rev. 95, 95-96 (1997) (casting doubt on whether the Line Item Veto Act, P.L. 104-130, would have the dramatic effects on expanding executive power or reducing the federal deficit as Members of Congress predicted).

73 Elena Kagan, Presidential Administration, 114 Harv. L. Rev. 2245, 2254 (2001). 
tee, then chaired by Senator Ted Kennedy. In almost every case, the result of deregulation was to improve consumer welfare through lower prices, better service or both. ${ }^{74}$

The evidence from this episode is consistent with the premise for abolition of the independent administrative agency system more generally. Kagan's suggestion is for the President simply to assume the duties of the independent agencies under Article II of the Constitution. For this to succeed, the Supreme Court would have to reverse or distinguish its holding in Humphrey's Executor v. United States, a Depression Era decision upholding Congress's right under Article I to delegate some of its powers to the agencies without thereby granting supervisory power to the President. ${ }^{75}$ Members of Congress would then have reduced influence on policy making by the agencies. Elite interests may face greater resistance within the executive branch than in the legislature. For analysis of the impact of Humphrey's Executor on the Madisonian separation of powers see Rao, note 49, supra.

However, giving the President responsibility for the work of the independent administrative agencies runs into the same difficulty as relying on the President to veto corrupt legislation. The President has political reasons to permit some corrupt activity that a disinterested monitor would lack. Further, there are many agencies, parts of the executive branch, where congressional influence exercised through oversight and appropriations dominates presidential control.

\section{G. DIRECT DEMOCRACY ${ }^{76}$}

The golden age of Athenian democracy relied on direct government by the people. All citizens could vote on matters of policy. Functionaries, including military leaders, were either directly elected or selected at random from the citizenry for very brief terms. This system was-and still is—much admired

74 Winston surveys studies of the effects of deregulation. See generally Clifford Winston, Economic Deregulation: Days of Reckoning for Microeconomists, 31 J. Econ. LitERATURE 1263 (1993). The Reagan administration and others later rolled back banking regulation including, unfortunately, financial institution risk-taking and private institutions that are "too big to fail," and thus subsidized with lower capital costs at public expense.

75295 U.S. 602, 628, 631-32 (1935) (finding that Congress could limit the President's ability to remove the Chairman of the Federal Trade Commission to removal "for cause," because the FTC's authority mixed executive, legislative, and judicial functions, and thus "cannot in any proper sense be characterized as an arm or an eye of the executive ... and "must be free from executive control").

76 For surveys of the literature on direct democracy, especially the cognitive challenges associated with voting in complex referenda, see generally SHAun Bowler \& TODD Donovan, Demanding Choices: Opinion, Voting, and Direct Democracy (1998), and Arthur Lupia \& John G. Matsusaka, Direct Democracy: New Approaches to Old Questions, 7 Ann. Rev. Pol. Scr. 463 (2004). 
by political philosophers. It eliminates or at least reduces to an irreducible minimum the problem of agent corruption. However, the Athenian system was flawed in several ways. It was not inclusive-noncitizen residents, women, and slaves could not participate. The Assembly suffered from the natural defects of "crowd-sourcing"-a weakness for impulsivity and a tendency to be guided by emotion and demagoguery rather than logic and knowledge. A standard example is the Athenian Assembly's disastrous decision, described by Thucydides, to invade Sicily in 415 B.C. 77

Direct democracy has avid advocates even today. Modern technology offers potential solutions to the problem of voter numerosity. Political scientists such as Fishkin have offered methods (and some evidence from experiments with a "deliberative" decision process) designed to overcome voter ignorance, emotional motivations, and free rider incentives. ${ }^{78}$ Of course, any direct process is subject to (and would rely in part upon) persuasive advocacy by well-organized and well-funded interests. Bias in favor of those interests is the likely result.

McCormick, channeling some of Machiavelli's lesser-known work, ${ }^{79}$ has suggested reliance on a system of selecting legislative representatives at random from among eligible citizens, excluding those from the elite class. ${ }^{80}$ That may preserve the advantages of having full-time representatives while eliminating corrupting incentives related to election and re-election campaigns. However, random selection would not eliminate corrupting influences arising from imbalanced interest group lobbying. Juries may be sequestered, but not legislators. A citizen selected at random for a brief term in Congress, with no chance of serving a second term, would be particularly dependent on interest group sources of information and professional advocacy.

\section{H. LIMITED GOVERNMENT}

A traditional conservative or libertarian perspective is that political corruption is an inevitable consequence of big government, with an obvious remedy: less government. However, that does not solve the problem of corruption. This remedy ignores the likelihood that the People simply prefer many or most of the entitlement and regulatory programs that inhabit the expanded sphere of federal jurisdiction. If so, reducing the scope of the federal jurisdiction would likely require devolution of these programs to the

77 Alan Ryan, On Politics: A History of Political Thought: From Herodotus to the PResent 25-28 (2012).

78 James S. Fishkin, When the People Speak: Deliberative Democracy and Public Consultation 21-31, 95-105 (2009).

79 Niccolo Machiavelli, Discourses on the First Ten Books of Titus Livius, reprinted in The Prince and the Discourses 99 (Christian E. Detmold trans., Random House, Inc., 1950) (1531).

80 John P. McCormick, Machiavellian Democracy 183-85 (2011). 
individual states. State governments face many of the same problems with political corruption as the federal jurisdiction. Pushing the problem down one level does little or nothing to solve it. Nevertheless, effective remedies on a state-by-state level could include those considered here.

\section{WATCHDOGS AND WHISTLEBLOWERS}

The growth of the Internet has greatly reduced the cost of communicating specialized information to large audiences. One result has been the creation of numerous "watchdog" organizations, both partisan and nonpartisan, publicizing lapses by legislators and agencies. The category overlaps with investigative journalism and with individual government employees ("whistleblowers") who leak and publicize agency misdeeds, especially those that officials attempt to conceal. The most famous recent whistleblower, and certainly the most effective in bringing about change, is Edward J. Snowden, who passed secret U.S. government documents to web sites and newspapers. The documents revealed extensive, and arguably unlawful, government monitoring of private communication of U.S. citizens. ${ }^{81}$

Watchdogs and whistleblowers have a potentially important role, like all media, in making the public aware of dubious government policies and procedures. Several factors, however, reduce their effectiveness in combating welfare-reducing corruption. First, partisan sources or public donations typically fund these organizations; in either case, the nature of the funding source and any watchdog's need for continued funding introduces a source of bias that limits its credibility. Second, watchdog organizations seldom are staffed with the skilled analysts equipped to assess the impact of highly technical legislation and regulatory policies on the welfare of those affected. Third, watchdog groups have no direct power to intercede because they cannot end the harm caused by corrupted legislation and regulation.

\section{QUALITY CONTROL-IN BUSINESS, SPORTS, AND POLITICS}

The preceding discussion of popular remedies for political corruption focuses on the selection and regulation of elected representatives and factions. None of these remedies have been (or would appear to be) effective or, in some cases, practicable. It is useful to step back at this point and ask how nongovernment organizations mitigate principal-agent corruption

81 Julia Angwin et al., AT\&T Helped U.S. Spy on Internet on a Vast Scale, N.Y. TImES (Aug. 15, 2015), http://www.nytimes.com/2015/08/16/us/politics/att-helped-nsa-spyon-an-array-of-internet-traffic.html. 
(or equivalently, increase principal-agent incentive compatibility). Leaving aside formal civil and criminal legal remedies, such measures include relational contracts with suppliers and employee compensation designs mostly inappropriate to political representation. ${ }^{82}$

A more general approach in commercial contexts is quality control. Quality control (of products and services) includes the incentive-related measures just mentioned but is grounded on direct measurement and evaluation of outcomes. Firms inspect and test finished products and services for adherence to design specifications and customer satisfaction. A feedback loop adjusts organizational practices and incentive structures.

Law in its various forms is a major "output" of the administrative state. (Increasingly, the federal government outsources or delegates to the states the actual delivery of government services. ${ }^{83}$ ) The output of law is of poor quality, in part because of corruption, but also due to poor or no quality control. ${ }^{84}$ Compared to ordinary practice in the private sector, there is only vestigial or nominal attention to the relationship between output and the well-being of clients. Corrupted elections are a poor substitute for best-practice quality control. Law at the national level is a monopoly of the state; competitive discipline is absent. The rivalry that stems from the separation of powers is seldom about substantive policy; it is chiefly about branch jurisdiction. The rivalry may protect against tyranny but it does little to forestall corruption.

Quality filters such as presidential vetoes and judicial review attend only to a small subset of legislation and seldom address the general welfare objective of the Preamble. The filtering role of the media is confined to issues of high salience that do not correspond systematically to issues that most deeply impugn welfare. The media seek to produce audiences, chiefly by appeal to emotion, especially fear. By reporting on criminal corruption and high-visibility boondoggles (such as the Alaskan "bridge to nowhere" ${ }^{85}$ ), the media incite contempt for politicians but not attention to the welfare and distributional consequences of lawful corruption.

82 For discussions on economic models of intraorganizational incentive structures compatible with improved or optimal organizational performance, see generally, Philippe Aghion \& Richard Holden, Incomplete Contracts and the Theory of the Firm: What Have We Learned over the Past 25 Years?, 25 J. Econ. PersP. 181 (2011); Robert Gibbons, Four Formal(izable) Theories of the Firm, 58 J. Econ. Behav. \& Org.200 (2005).

83 One scholar has noted the trend toward outsourcing or "privatizing" government services, analogizing that trend to the creation of the administrative state in the middle of the last century, and speculating on the implications for, among other constitutional matters, the separation of powers. See Jon D. Michaels, An Enduring, Evolving Separation of Powers, 115 Colum. L. Rev. 515, 570-72 (2015).

84 SCHUCK, supra note 8, at 161-97 (examining public policy failures that arise from poor information, rigidity, lack of cooperation, and mismanagement).

85 Carl Hulse, Two 'Bridges to Nowhere' Tumble Down in Congress, N.Y. Times (Nov. 17, 2007), http://www.nytimes.com/2005/11/17/politics/two-bridges-to-nowhere-tumbledown-in-congress.html. 
In a Madisonian government the most natural way to interdict corrupted law (and thereby to deter its instigation) in one branch is to assign another branch the responsibility and power to monitor and constrain the effects of processes that have been corrupted. ${ }^{86}$ (See Madison's argument in The Federalist No. 10, which includes the epigraph at the beginning of this Essay.) To accomplish this, we need an "independent" monitor, with the power to assess and veto legislation and agency policy that fails substantively to advance the aims of government set out in the Preamble. Such a function could supply Madisonian intramural discipline focusing on the welfare reductions produced by elite rent seeking.

The American people are familiar with the roles of umpires, referees, and kindred officials in sports contests. In addition, while umpires strive to score pitches and runs accurately, their task is to look at plays, not the recruitment of players. The focus generally is on output or performance, not inputs or form. Partisans do often question the rulings of umpires and refs, and sports officials sometimes accept bribes or bet on the outcome of contests, but for the most part sports officiating is credible. Teams and leagues aim to make profits for their owners, an objective that requires, among other things, credible officiating of games. In a sense, sports teams and leagues are analogous to the People in a democracy in needing to monitor and maintain the credibility of officiating and competition by the players on the field. This is not accomplished by asking baseball fans to elect umpires.

Madisonian democracy recognizes the People themselves as the only legitimate source of political power. However, Madisonian democracy also recognizes that the People are unreliable-even dangerous-as a source of day-to-day legislative action. Instead, the People entrust their power to elected representatives. As noted above, this makes elected officials the agents, in an important sense, of the People.

All agents are unreliable to some degree because of self-interest, particularly if their performance is difficult to monitor or evaluate. Madison relied on competitive elections to control this conflict of interest. We can assume that Madison understood that elections would be biased if the partisan influences on voter choices are biased, but saw no better option. In the modern world, voters are woefully bad judges of the performance of their political agents. Voters generally are incapable of monitoring the performance of legislators, at least on non-salient issues.

Unlike private businesses, legislators are not vulnerable to product liability lawsuits. It would be an improvement to rely on disinterested professional umpires to decide which legislative "plays" are welfare-enhancing and which are not, particularly if the umpires themselves could be insulated from the political processes that lead to corrupt laws and policies.

86 See The Federalist No. 10 (James Madison). An umpire role is useful not only in mitigating lawful corruption but also in detecting errors and non-corrupt promotion of local constituent interests at the expense of the general welfare. 
The judicial branch is the sort of umpire that qualifies as a Madisonian element of government. The courts have many roles, but their umpire role is to protect citizens from infringements of constitutional or other rights by other branches of government. Article III courts, while not immune from human failings, are generally trusted by the public - at least more so than the other Madisonian branches. ${ }^{87}$ The courts could be helpful in stemming lawful corruption if they were competent and willing to police not just the infringement of rights, but also infringements of welfare, or else to treat freedom from government interference with the pursuit of happiness as a negative right.

As with the canonical branches of government, no one should expect perfection from a new "officiating" branch. Welfare-oriented umpires will not perfect or "optimize" the output of law, but at least welfare and equity issues will have a place, and an institutional advocate, in the debate. No less important, insulated umpires will reduce the elite bias that infects current lawmaking. As for legitimacy, what matters in the end is whether people trust the government to act in their interests. Despite being thoroughly undemocratic, the judiciary is seen as far more trustworthy than Congress, and an umpiring branch may usefully rely on similar organization features.

This Essay does not explore the technical means by which to assess the welfare and distributional effects of law. Modern benefit-cost-risk-distribution analysis seeks to include assessments of the significant values citizens place on environmental amenities (such as clean air and water), public services, and policy preferences, including preferences for distributional equity. The literature is enormous. ${ }^{88}$

Ultimately, of course, the question is whether a given law or policy increases happiness, compared to the status quo or some counterfactual, and of what relevant categories of the population. Suffice it to say for present purposes that the practice of benefit-cost-risk-distribution analysis applied to legislative impact is no less objective, reliable, or accurate than the constitutional and statutory analysis carried out by the Supreme Court. We accept the Court's decisions not because its reasoning is convincing-obviously it

87 Confidence in Institutions, supra note 47; Trust in Government, supra note 47.

88 See, e.g., Adam Davidson, The Economy's Missing Metrics, N.Y. Times Mag. (July 5, 2015), http://www.nytimes.com/2015/07/05/magazine/the-economys-missing-metrics. html; Jason J. Fichtner \& Patrick A. McLaughlin, Legislative Impact Accounting: Rethinking How to Account for Policies'Economic Costs in the Federal Budget Process 3 (George Mason Univ. Mercatus Ctr. Working Paper, 2015), available at http://mercatus.org/publication/legislative-impact-accounting-rethinking-how-account- policieseconomic-costs-federal; John F. Helliwell et al., Empirical Linkages between Good Government and National Well-Being 1-4, 17-18 (Nat'1 Bureau of Econ. Res., Working Paper No. 20686, 2014), available at http://www.nber.org/papers/20686; Richard Williams \& James Broughel, Principles for Analyzing Distribution in Regulatory Impact Analysis 1-2 (George Mason Univ. Mercatus Ctr., Mercatus on Policy Working Paper, 2015), available at http://mercatus.org/publication/principles-analyzing-distributionregulatory-impact-analysis. 
is not convincing to the dissenters-but because we accept the legitimacy of the rule of law, imperfect as it is, and the necessity for finality.

How could we include umpires in the current Madisonian system? Several possibilities suggest themselves.

\section{A. Substantive Review in the Supreme Court}

The United States lacks a constitutional court separate from its judicial court of last resort. According to Article III of the Constitution, the Supreme Court was to be a court of last resort for the resolution of disputes. John Marshall, Chief Justice of the Supreme Court from 1801 to 1835, believed that his Court should also be a constitutional court with the power to strike down federal legislation that was inconsistent with the Constitution. In Marbury v. Madison, 5 U.S. 137 (1803), the Court awarded itself the right to a line item veto. At a stroke, this made the judiciary a coequal branch of government. Congress might have challenged this usurpation by initiating an Article $\mathrm{V}$ amendment process, but did not. ${ }^{89}$

Article III does not require any judge to have legal training, but the Supreme Court has always been made up of lawyers. The Court's appellate role makes the appointment of lawyers natural. Other countries, however, often have separate constitutional courts, to which non-lawyers are appointed. France, for example, has the Conseil Constitutionnel (Constitutional Council) on which former presidents of the Republic and other distinguished citizens sit. The Conseil rules on constitutional questions referred to it by any legislator, agency, or citizen.

Because it is made up of lawyers, the U.S. Supreme Court approaches constitutional questions much as it approaches appellate review of cases: focusing chiefly on "matters of law" which are either procedural or involve statutory interpretation, giving much emphasis to precedent, and mostly ignoring substantive effects on welfare. Perhaps worse, for present purposes, it is constrained by "legal reasoning," a mode of justification for changes in law in which several factors are alleged to motivate or limit some prior action or doctrine, with respect to which the Court may now assign different subjective weights.

A 2015 Supreme Court decision dealing with Environmental Protection Agency (EPA) regulation of mercury emissions from coal-burning power plants illustrates the problem..$^{90}$ The question was whether the EPA should consider costs in deciding to impose regulation. It was undisputed that the costs of compliance would exceed $\$ 10$ billion per year, while the

89 There is debate whether the power of judicial review of legislation was inherent in the British common law imported to America. See, e, g., Dudley Odell McGovney, The British Origin of Judicial Review of Legislation, 93 U. PenN. L. Rev. 1, 1-2 (1944). If it was, there was no "usurpation" by the Marshall Court.

90 Michigan v. EPA, No. 14-46 (U.S. June 29, 2015). 
benefits would be well under $\$ 100$ million per year. An assessment of the effect on aggregate well-being, on these facts alone, would lead one to reject the proposed regulation. However, the Court could reach this commonsense result only through a tortuous analysis of the Clean Air Act, the Administrative Procedure Act, canons of statutory interpretation, and other legal materials. In the end, the Court's legal analysis rests in large part on the observation it would be unreasonable for the EPA (or the Congress) to ignore cost. This, despite numerous instances in which Congress has mandated explicitly that costs be ignored in environmental matters, notably in connection with endangered species. ${ }^{91}$

A more catholic constitutional court would consider substantive analysis of effects and treat "facts" as within its competence. What this suggests, unfortunately, is that the U.S. Supreme Court is unlikely to be comfortable asserting a position that would be perfectly natural for the French Conseil-for example, that a statute was unenforceable because its substance or effect was inconsistent with the general welfare standard in the Preamble to the Constitution, or with its "spirit." Still, the modern Court has "found" all sorts of new rights and entitlements in the Constitution just as the Marshall Court "found" a momentous new right for itself.

Whether the U.S. courts would accept economic well-being and collective action pathology as a new dimension of the nebulous concept of due process may be the key to tacit acceptance of an umpire role. Richard Hasen, advocating such a development, admits that "[d]espite longstanding public and scholarly concern about rent-seeking, I am aware of no court that has ever considered whether national economic welfare could be considered a sufficiently important (even compelling) government interest that could justify [anti-]lobbying (or other) laws." 92 An exception is the forlorn dissent in Citizens United:

When large numbers of citizens have a common stake in a measure that is under consideration, it may be very difficult for them to coordinate resources on behalf of their position. The corporate form, by contrast, "provides a simple way to channel rents to only those who have paid their dues, as it were. If you do not own stock, you do not benefit from the larger dividends or appreciation in the stock price caused by the passage of private interest legislation.” ... Corporations, that is, are uniquely equipped to seek laws that favor their owners, not simply because they have a lot of money but because of their legal and organizational structure. Remove all restrictions on their electioneering, and the door may be

91 "The plain intent of Congress in enacting this statute was to halt and reverse the trend toward species extinction, whatever the cost." Tenn. Valley Auth. v. Hill, 437 U.S. 153, 184 (1978) (interpreting the Endangered Species Act of 1973).

92 Hasen, supra note 47, at 235. 
opened to a type of rent seeking that is "far more destructive" than what noncorporations are capable of. ${ }^{93}$

The relatively narrow traditional perspective of the U.S. Supreme Court is unfortunate because the Court represents the least controversial of the possible means to establish a credible umpire function within the existing Madisonian system. As John Marshall demonstrated, no formal amendment is required for the Court to assert such a power, although a modern Court would doubtless move with greater diffidence than did Marshall. One way to begin might be for a President to appoint a distinguished nonlawyer to the Court. ${ }^{94}$

\section{B. Agencies RESPONSIBLE FOR POLICy EVALUATION: OMB, CBO, GAO}

Other solutions to the problem of creating a legitimate and credible umpire to serve as a substantive filter for legislative and administrative corruption seem to require a constitutional amendment. ${ }^{95}$ Any number of existing agencies, including the Office of Management and Budget (OMB), the $\mathrm{CBO}$ and the GAO have the necessary expertise to make such judgments, but lack not only the authority to veto legislation or administrative actions but also the political legitimacy to survive resulting push back. Some better method for appointing umpires would be required, such as presidential appointment with supermajority senate confirmation. Those distressed by "gridlock" in Washington today clearly will be even more distressed to consider yet another locus of veto power over legislation. ${ }^{96}$ The first response to this is that veto points in the legislative process have proliferated precisely because of systemic corruption; each veto point provides an opportunity to extract payments from elite interests, rather like the highway holdups operated by "rebel" groups in lawless nations. Alternatively, one can argue that from a Madisonian perspective it is not so obvious that gridlock is a bad thing. It is a natural result of the checks and balances established to protect the People from ill-considered laws. Further, if a fourth branch of umpires existed, it would deter expenditures on corrupted legislation likely

93 Citizens United v. FEC, 558 U.S. 310, 471 (Stevens, J., concurring in part and dissenting in part) (quoting Robert H. Sitkoff, Corporate Political Speech, Political Extortion, and the Competition for Corporate Charters, 69 U. CHI. L. REv. 1103, 1113 (2002)).

94 For a summary (and negative assessment) of proposals to subject regulatory decision making to stricter judicial review, see FuKUYAMA, supra note 5, at 467-476, and Einer R. Elhauge, Does Interest Group Theory Justify More Intrusive Judicial Review?, 101 YALE L.J. 31, 33-35 (1991).

95 Anything at all can be done, of course, without an amendment if none of the branches opposes it. See Ginsberg \& Melton, supra note 70, at 1, 22-23, for an argument that amending the Constitution may not be so difficult as is commonly supposed, and Part 8 below for an argument supporting the feasibility of an Umpire Amendment.

96 See supra note 55. 
to produce an umpire veto. Paraphrasing Oliver Wendell Holmes, Jr., expectations of what umpires will do deter most rule infractions, not official action on every latent player impulse. ${ }^{97}$

\section{THE GRAND JURY}

The grand jury is a potential model for an umpiring institution. The most obvious advantage is that the traditional federal grand jury already can be characterized as a fourth branch of government, and one designed to check abuse of government power.

"[R]ooted in long centuries of Anglo-American history," ... the grand jury is mentioned in the Bill of Rights, but not in the body of the Constitution. It has not been textually assigned, therefore, to any of the branches described in the first three Articles. It "is a constitutional fixture in its own right." ... In fact the whole theory of its function is that it belongs to no branch of the institutional Government, serving as a kind of buffer or referee between the Government and the people. ${ }^{98}$

The grand jury is, at least in theory, independent of the executive branch, the legislative branch and even the judiciary, though it interacts with each. In centuries past the grand jury has from time to time bravely interceded to resist excesses of the executive, ${ }^{99}$ but today it more commonly is accused of being a mere rubber stamp for prosecutors.

With a membership between sixteen and twenty-three citizens subject to the same qualifications as members of a petit jury panel, the federal grand jury is supposed to protect potential criminal defendants from abuse by politically appointed prosecutors. The grand jury votes on the sufficiency of the prosecutor's evidence to justify an indictment, a majority but no fewer than twelve votes being the minimum required to indict. Proceedings are conducted pursuant to Title III, Rule 6 of the Federal Rules of Criminal Procedure, which is a product of the legislature. A judge of the local district court has limited supervisory duties and issues subpoenas on behalf of the jury. At the state level, the duties of grand juries sometimes extend to civil matters. One state, California, has a "civil" grand jury in each county con-

97 "The prophecies of what the courts will do in fact, and nothing more pretentious, are what I mean by the law." Oliver Wendell Holmes, The Path of the Law, 110 Harv. L. Rev. 991, 994 (1997).

98 United States v. Williams, 504 U.S. 36, 47 (1992).

99 See, e.g., Richard H. Kuh, The Grand Jury 'Presentment': Foul Blow or Fair Play?, 55 Colum. L. Rev. 1103, 1108-09 (1955) (noting the acquittal of Peter Zenger on charges of criminal libel against the British Crown by a New York colonial grand jury); Milton Nahum \& Louis M. Schatz, The Grand Jury in Connecticut, 5 Conn. B.J. 111, 113 (1931) (noting another, similar example from the colonial period). 
cerned with investigating and recommending local government efficiency or policy reforms.

The essential elements of the traditional grand jury for present purposes are its common law role of protecting citizens from the power of the state, its status as an agency outside the formal Madisonian framework, its composition of up to twenty-three ordinary citizens chosen at random, and its reliance on a professional staff to coordinate investigations. The work of the grand jury is defined by common law and statute. Arguably, the Congress could create a grand jury tasked with discovering and "indicting" corrupt law, bypassing the need for a constitutional amendment.

There are some obvious problems with relying on repurposed grand juries to serve as umpires. The power of a grand jury lies in denying permission for the state to prosecute an alleged criminal when the prosecutor has insufficient basis to justify a trial. Even "civil" grand juries are limited to making reports and recommendations. Congress would have to give an umpire grand jury the power to veto a law or regulation on the basis that the law reduced the "general welfare." That is a lot of weight for the grand jury institution to bear-a change from protecting individual citizens from abuse of state power to protecting the People as a whole from abuses of state power.

\section{UMPIRES OF THE PAST}

There are at least two precedents for an umpire role in a republican form of government. One is the "Council of Revision" 100 that existed briefly in New York State under its 1777 postcolonial Constitution, Article III of which stated:

And whereas laws inconsistent with the spirit of this constitution, or with the public good, may be hastily and unadvisedly passed: Be it ordained, that the governor for the time being, the chancellor, and the judges of the supreme court, or any two of them, together with the governor, shall be, and hereby are, constituted a council to revise all bills about to be passed into laws by the legislature; and for that purpose shall assemble themselves from time to time, when the legislature shall be convened; ... And that all bills which have passed the senate and assembly shall, before they become laws, be presented to the said council for their revision and consideration; and if, upon such revision and consideration, it should appear improper to the said council, or a majority of them, that the said bill should become a law of this State, that they return the same, together with their objections thereto in writing, to the senate or house of assembly ... who shall enter the objection sent down by the council at large in their minutes, and proceed to reconsider the said bill. But if, after

${ }^{100}$ I am indebted to Jack Rakove for pointing me to this episode. 
such reconsideration, two-thirds of the said senate or house of assembly shall, notwithstanding the said objections, agree to pass the same, it shall together with the objections, be sent to the other branch of the legislature, where it shall also be reconsidered, and, if approved by two-thirds of the members present, shall be a law. ${ }^{101}$

The other and more substantial example of an official umpire charged to protect the interests of the People from the self-interest of the legislature and the executive is the "Tribune of the Plebs," an elective office under the Roman Republic (c. 500-27 в.с.). The Oxford Classical Dictionary describes the Roman "Tribunate" as follows:

The tribuni plebis (or plebi), 'tribunes,' were the officers of the plebs first created ... traditionally in 494 в.С ... The tribunes were charged with the defense of the persons and property of the plebeians ... Elected by the plebeian assembly and exercising their power within ... the city, the tribunes could summon the plebs to assembly and elicit resolutions (plebiscita). They asserted a right of enforcing the decrees of the plebs and their own rights ... They possessed ... a right of veto against any act performed by a magistrate ... The full acknowledgement of their power came with the recognition of plebiscita as laws binding upon the whole populus and not just the plebs ... Tribunes were first admitted to listen to senatorial debates; at least from the $3^{\text {rd }}$ cent. BC they had the right to convoke the senate; ... In the first surviving contemporary discussion of the tribunes, from about the middle of the $2^{\text {nd }}$ cent., Polybius ... states that 'they are bound to do what the people resolve and chiefly to focus upon their wishes.' Succeeding years saw the tribunate active in the pursuit of the people's interest and the principles of popular sovereignty and public accountability, as evidenced by the beginning of the practice of addressing the people in the forum directly, the introduction of the secret ballot in assemblies, concern with the corn supply agrarian legislation, $\ldots$ and above all by the legislation and speeches, for which contemporary evidence survives, of Gracchus (123-122 в.с.)... Active tribunes came increasingly to be associated with the particular interests and grievances of the urban plebs ... ${ }^{102}$

Briefly, the socioeconomic class called the "plebs" became restive under the tyranny of the aristocratic families that collectively ruled the Roman Re-

101 The Federal and State Constitutions, Colonial Charters, and Other Organic Laws of the States, Territories, and Colonies Now or Heretofore Forming the United States of America 2628-29 (Francis Newton Thorpe ed., 1909) (emphasis added); see also Robert L. Jones, Lessons from a Lost Constitution: The Council of Revision, the Bill of Rights, and the Role of the Judiciary in Democratic Governance, 27 J.L. \& PoL. 459, 464, 485-88 (2012) (discussing the Virginia Plan's proposal for a "Council of Revision," presented at the 1787 constitutional convention).

102 Tribuni plebis (or plebi), Oxford Classical Dictionary (3d ed. 2002). 
public and staged a credible boycott. The aristocracy and the plebs negotiated a lasting settlement that granted substantial political power to the elected representatives of the plebs. The Plebeian Assembly held these Tribunes of the Plebs to nonrenewable one-year terms. The Tribunes do seem to have sought generally to protect the interests of the plebeian class for several hundred years. ${ }^{103}$

Our understanding of the political operation of the early Roman Republic is limited; most surviving materials were created centuries after the fact. Still, what we do know of the Plebeian Tribunate offers a useful model for a modern umpire that might reduce the social cost of political corruption, using the veto power. The relevance of the Tribunes to mitigation of modern systemic corruption is twofold: the Tribunes protected the people (or at least the plebs) from executive and legislative actions adverse to plebian interests, and they did so ex post-after the legislation or action was enacted or ordered.

Of all the remedies discussed above, the establishment of an effective umpire function seems most likely to succeed in mitigating lawful corruption. The major difficulty is not the necessity to find consensus on some very important details (illustrated in Part 7), but rather the barrier of formal constitutional amendment, assuming that hurdle proved unavoidable.

No one thinks that either method of amendment under Article $\mathrm{V}$ is easy or riskless. Indeed, the prospect of a convention is positively scary, given the 1787 precedent. As noted above, the Constitution is usually amended tacitly by the Supreme Court in the course of interpretation. Something like that likely will have to precede full realization of an umpire institution willing and able to call strikes on lawful political corruption. For example, perhaps a President could delegate "advisory" veto authority to a new organization within the executive branch, made up of umpires. This in itself would do little if anything to reduce corrupt legislation, but it might evolve into a more effective force, without the need for a formal amendment.

Even a common understanding of "human nature" as given to us by a complicated mixture of nature and civil nurture should leave no one surprised at manifestations of antisocial tendencies in principal-agent relations, including political representation. That is why we have so many

${ }^{103}$ The earliest surviving account of the Tribunate, by Polybius (c. 160 b.c.), likely paints too rosy a picture of the tribunes' effectiveness. See generally Polybius, The Histories (Robin Waterfield trans., 2010) (c. 160 B.C.). In addition, it would be a mistake to regard the plebs as "the People" in a modern sense. As in classical Athens, women, slaves, and (perhaps) those who lacked land ownership were excluded, and participation in the Plebeian Assembly was determined by tribal membership. McCormick explores the advantages of reviving the Tribunes of the Plebs as a modern solution to the problem of political corruption. MCCoRMICK, supra note 80 at 178-88. Posner provides a political economy perspective on the Roman constitution, including the tribunes. Eric A. Posner, The Constitution of the Roman Republic: A Political Economy Perspective 17-29 (John M. Olin Law \& Econ., Working Paper No. 540, 2010), available at http:// ssrn.com/abstract $=1701981$. 
mechanisms to contain it: audit trails, supervision, morality, religion, civil, criminal and reputational penalties, conscience, and so on. Political corruption in America is far from costly to its authors-it is a near requirement of holding a congressional seat, and it is boring to voters and media audiences. We need something more effective than dreams of direct democracy, a return to limited government, or easily evaded controls on interest group activity. If we are to retain the bones of Madisonian democracy and still avoid the growing economic and equitable costs of corruption, we must tweak the Madisonian system. That calls for a branch whose only business it is to monitor and edit Washington's massive output of corrupt law.

\section{IlLustrative DETAILS}

For the sake of concreteness, and in emulation of McCormick, ${ }^{104}$ I set out below some candidate features of a new or fourth branch of the federal government designed to reduce the impact of legislative and administrative error and corruption on the well-being of the People. In political terms, the illustrative proposal is intended to counter the influence of elite interests in the legislature and the administrative process with a democratic institution representing the principal victims of elite power, the middle class. ${ }^{105}$ As with any Madisonian system, the effect of such a new branch would be felt chiefly through changes in the incentives of the remaining branches.

The Constitution and its amendments leave most details up to future implementers. If we are to follow this tradition, only the most important provisions should be included in the "umpire amendment." Which ones are most important? Not necessarily those I have chosen to include in this illustration.

104 See McCormick, supra note 80, at 170-188 (conducting a "thought experiment" on institutional reform).

${ }^{105}$ For clarity, although the poor merit special attention and succor, they are not the rational targets of elite corruption; the poor have little worth stealing, and the harm done to them by corruption is the result of systemic efficiency losses. The middle class still has a collective share of half or more of the pie - an amount worth stealing through, for example, corrupted tax, trade, and regulatory policies. 


\section{A. The Umpire Amendment ${ }^{106}$}

\section{The United States Council of Review ${ }^{107}$}

Article 7.1.1.

(a) Promotion of the general welfare of the People being chief among the purposes of government, there is established a Council of Review, which shall not be within the branches established by Articles I, II or III of the Constitution. ${ }^{108}$

(b) The Council may veto any Law or provision thereof judged likely to reduce the well-being of the People or that of the poorest citizens. ${ }^{109}$

${ }^{106}$ Republican members of the House and Senate introduced a bill in 2015 that bears some procedural and substantive similarities to the umpire proposal described below. See SCRUB Act of 2015, S. 1683, 114 ${ }^{\text {th }}$ Cong. (2015); SCRUB Act of 2015, H.R. $1155,114^{\text {th }}$ Cong. (2015); H.R. Rep. No. 114-196, pt. 1, at 2-7 (2015).

107 The anodyne term "Council of Review" may dampen emotional reactions both for and against the proposal.

108 The Council's jurisdiction is limited to the "general welfare" clause, excluding the remaining enumerated goals in the Preamble, in order to keep its mission focused and its power within bounds. Lawful corruption affects official behavior on many issues, not just those that reduce well-being. Weisman and Confessore describe a recent example in a front-page article in the New York Times. Jonathan Weisman \& Nicholas Confessore, Donors Descend on Schumer and Others in Debate on Iran, N.Y. Times (Aug.12, 2015), http://www.nytimes.com/2015/08/13/us/politics/in-efforts-to-sway-iran-debate-big-money-donors-are-heard.html. The story describes donations made to Senator Chuck Schumer by rival groups supporting or opposing the proposed agreement with Iran restricting its capability to produce nuclear weapons. Senator Schumer is not up for reelection but is understood to need money in aid of his potential candidacy to lead his party in the Senate. (Donations of campaign funds to other politicians, or to party coffers, greatly influences selection for congressional leadership posts. Eliza Newlin Carney, Money Dominates Committee and Leadership Races: Rules of the Game, RoLL CALL (Nov. 19, 2014, 5:00 AM), http://blogs.rollcall.com/beltway-insiders/moneydominates-committee-and-leadership-races-rules-of-the-game/.) The point of the story for present purposes is that it is money from interest groups rather than a calculation of constituent interest that is thought to influence Senator Schumer's position. Senator Schumer's position is a political matter with no clear impact on aggregate well-being or on the distribution of income. Therefore, it is not the sort of matter with which the Council should be concerned.

109 Such phrases as "general welfare," "well-being," and the like are not well defined. Within the founding documents the term whose meaning best serves as a bridge between the terminologies of 1788 and today is "happiness." Happiness is something that people "pursue;" according to the Declaration it is one of the purposes of government to facilitate that pursuit. Current social science and neuroscience shed a great deal of light on what that means as a practical matter and how to measure it. The science of happiness is not settled in the same way that we think (incorrectly) of physics as "settled" science, but it is certainly no less settled than the application of law to dis- 
(c) For purposes of this Amendment, Law shall mean any provision or related provisions ${ }^{110}$ of the United States Code, the Code of Federal Regulations, or a Bill enacted during the preceding congressional session. ${ }^{111}$

(d) The Council's action shall take effect when Congress next adjourns, except that a two-thirds majority in each House of Congress may override the Council's action. ${ }^{112}$

Article 7.1.2.

(a) Any citizen of the United States, having voted in six of the last seven federal elections and meeting other standards, established by law, of character, education, and mental fitness may apply to join the Council. ${ }^{113}$

(b) A new Member shall be selected by lot from among qualified applicants within 45 days of a vacancy, for a term to begin no later than 90 days after selection.

(c) Members shall serve a term of 15 years. ${ }^{114}$

puted matters. Perhaps "the general welfare" should be formally defined in the Umpire Amendment in terms of the average or aggregate happiness of the people, with the possible addition of other characteristics of its distribution, such as variance and skewness. The suggested anti-regressive redistribution clause could be left implicit in the general welfare purpose, because happiness includes components of altruism and policy preferences for living in a just society. But clearly from a moral perspective this component of happiness is particularly important.

110 This provides for line item vetoes. In dealing with enacted bills, it may be preferable to limit line item veto power to nongermane provisions. See supra note 72, discussing line item veto power.

111 There are many important timing and other issues associated with this broad definition of "Law." Perhaps Statutes at Large (or other codes) should be specified instead of or in addition to the United States Code.

112 Some enacted bills may require emergency action if the effect on well-being is immediate.

${ }^{113}$ I am grateful to Peter Owen for this suggestion. While it may be helpful to include a cap on applicants' prior year(s) earnings or wealth in order to exclude members of the elite, the restriction on lifetime income makes it very costly for those with high private sector incomes from wealth or employment to serve.

114 The composition of the Council, method of selection, and number of Members are each critical to issues of political independence, public trust, and competence. Having Members elected invites political corruption. Having Members appointed by, say, the President with Senate confirmation invites partisanship. Having only a few Members provides potential pressure points for influence; having many Members complicates discourse and may unduly potentiate the Council's professional staff.

The particular method described in 7.1.2 produces a Council of fifteen Members, with new appointments each year to fill vacancies. If new appointments were made four times a year the Council would have sixty Members; three appointments per year yields a membership of forty-five, and so on. Sixty or forty-five Members seems unwieldy for en banc discourse and decisions; fifteen may be the lower end of the range needed to discourage corrupting influences, particularly if all decisions to veto are re- 
Article 7.1.3.

(a) Members must swear or affirm an oath of office prescribed by law.

(b) For life upon their assumption of office, Members must renounce and divest to the Treasury all income from any source other than as described in this Article. ${ }^{115}$

(c) Members shall receive a salary, not less than twice the salary received by the highest-paid Member of Congress, which Congress may not vary during their term of office. ${ }^{116}$

quired to be en banc. Perhaps the number and method of selection of grand jurors is a useful precedent.

Choosing Members by lot from a very large panel invokes the legitimacy of modern petit juries as well as Athenian direct democracy. Imposing qualifications requirements (such as education) on the population of the panel tends to undermine legitimacy by suggesting elite bias. One middle ground might be random selection from a panel of middle-income or middle-wealth citizens, perhaps with moderate educational requirements such as at least two years of postsecondary schooling.

The particular suggestion in 7.1.2(a) would likely produce Members relatively well informed about public affairs, engaged, and reasonably well educated, because such people are more likely to vote. Existing studies of voting patterns by age, education, and the like will shed light on these issues. See, e.g., Jan E. Leighley \& Jonathan NAgler, Who Votes Now?: Demographics, Issues, Inequality, and Turnout in the United StATES 58-66, 72-76 (2014) (studying the relationship of education and age with voter turnout); Michael S. Lewis-Beck et Al., The American Voter Revisited $92-97$ (2008) (reviewing studies and finding positive correlation between eligible voters' interest in public affairs and the likelihood that they will actually vote); see also Ansolabehere \& Hersh, supra note 25 , at 456 (noting that people with a bachelor's degree are more likely to vote compared to those without). The details in the illustration imply a minimum age of at least thirty. Perhaps there should be a maximum age as well - do we want a random eighty-year old to be eligible for an office with a fifteen-year term? An alternative procedure combines nomination with random selection: The President, the Vice President, the Chief Justice, the Speaker of the House, the Majority Leader of the Senate, and the Minority Leaders of the Senate and House each nominate ten (10) candidates within forty-five days of a vacancy on the Council; that yields seventy nominations. Each vacancy on the Council is then filled, by lot, from among the nominees, with a two-thirds majority of the Senate required to confirm the candidate thus selected. The requirement of a two-thirds majority tends to discourage highly partisan or otherwise extreme candidates. Members of Congress, their first-degree relatives and senior staff may not be nominated until five years have elapsed since leaving office. (This and most other methods of choosing Members requires a start-up phase with, for example, initially staggered terms.)

${ }^{115}$ Implementers will need to deal with issues involving incomes of other family members, partially vested retirement savings and the like.

116 Salaries for Members of the Council must be set taking into account the effect of the restriction in clause 7.1.3(b) and the need to attract professional and other citizens away from careers that cannot be rejoined after service. Unlike elected officials, Council Members cannot expect income from post-service employment. 
(d) Congress shall by law provide for Members' salaries to be increased or decreased annually after the conclusion of their service in accordance with the increase or decrease in the per capita income of citizens of the United States, after adjustment for inflation.

(e) Members may receive limited and incidental income from appreciation in value of personal and residential real property, gifts unrelated to their office, and interest on loans made to the United States, as Congress may by law provide.

(f) Members may be removed by a two-thirds majority of the Council or by impeachment, and Congress may by law provide for the dissolution of such Members' rights or obligations under this Article.

[Article 7.1.4. $]^{117}$

(a) The Council shall publish the reasons for its decisions.

(b) Congress shall by law provide for the Council to compel testimony.

(c) The Council may, if it deems necessary, deliberate in secret.

(d) The Council shall elect, and may remove, its Chair, whose term shall last until the addition of a new Member.

(e) The Council and its Members shall be protected with judicial immunity.

(f) The Council may not override, or nullify a congressional override, of a presidential veto.

(g) The Council may, for purposes of its review, consider what alternative(s) would prevail if the subject matter of the review were vetoed. ${ }^{118}$

(h) The Council may decline to undertake any review requested of it. ${ }^{119}$

(i) A stay pending a decision whether to review a new Law may not exceed 45 days.

117 This bracketed article is a placeholder for provisions whose merit or wording is less obvious, or which perhaps belong in implementing legislation rather than in the Amendment. A related issue is the extent to which existing law and procedures, currently affecting other agencies, are applicable to the Council, which is not part of any branch. It may be useful to establish a default status of non-applicability in the absence of congressional action.

118 This is an important but easily overlooked issue. A law or regulation cannot be evaluated in isolation; its positive and negative effects on well-being must be assessed compared to something else, generally either the status quo ante enactment or some alternative law or regulation. The Council in some cases may have to make a political judgment as to the likely reaction of the government in the event of a veto.

119 Without control of its own docket, the Council could be overwhelmed with cases requiring review. Moreover, the Council should have the ability to pick and choose cases in a way consistent with guarding its credibility and establishing expectations that it will exercise its "prosecutorial discretion" strategically. For example, arguably the Council should avoid overturning Laws that, even if perhaps welfare-reducing, were enacted accompanied by extensive public awareness and debate, thus invoking Madisonian political legitimacy. See note 26, supra. 
(j) Any Law in effect upon ratification of this Amendment shall be subject to review by the Council for 10 years and thereafter for one year at 10-year anniversaries of the Law's enactment. ${ }^{120}$

(k) The Council may not veto a Law based solely on any provision of the Constitution except this Amendment, ${ }^{121}$ nor treaties except for those provisions concerning international trade and commerce, nor Laws concerning the armed services or national security, including declarations of war, except those provisions dealing with procurement. ${ }^{122}$

(l) The Council may consider the principles of stare decisis in its decisions. ${ }^{123}$

(m) The Council may not stay or veto appointments to federal executive or judicial offices made by the President with the advice and consent of the Senate. ${ }^{124}$

(n) The Chair shall appoint, with the consent of the Council, a Staff Director with a renewable 5-year term. ${ }^{125}$

(o) Professional employees of the Council shall serve "at will" and without tenure. Notwithstanding any provision of law to the contrary, the Council may offer staff compensation commensurate with that in the private sector.

(p) Neither a former Staff Director nor any former professional Council employee may earn income from representing or advising clients with business before the Council before five years after leaving employment.

${ }^{120}$ Older laws should not be exempt from review, but to make all older laws immediately subject to review may be unduly disruptive. From the point of view of the well-being of the People, the sensible thing would be to target first those Laws, old or new, that most significantly and directly reduce welfare. Of course, vetoing nearly any law requires careful analysis of its connections with a whole network of related laws and institutions. One cannot extract one building block, however flawed, from the base of a tower with considering the effect on the rest of the tower. The Council should be guided by the medical maxim, primum non nocere - first, do no harm.

${ }^{121}$ This is perhaps useful to distinguish the jurisdiction of the Council from that of the judiciary.

${ }^{122}$ Trade barriers and corruption in procurement are major sources of reduced well-being. Other areas of foreign and military policy often involve complexities that the Council may be ill suited to consider.

${ }^{123}$ One mechanism by which the Council protects welfare is by changing the incentives of elite interests and legislators. This requires that the actions of the Council be reasonably predictable.

124 This avoids excessive power in the Council and removes any temptation to speculate on the possible consequences of appointments.

125 This and the next two items may be useful in protecting the quality, independence, and integrity of the Council's staff. The Council is required to make decisions based on sometimes-complex quantitative analyses and economic reasoning. It is very important that the Council acquire and retain a competent staff of experts, analysts, and communicators, especially given the Members' amateur status. 
Article 7.1.5.

Congress shall authorize and appropriate such sums as are necessary to provide the Council with staff support and facilities sufficient to perform its duties, and may otherwise provide by law for the implementation of this Amendment. ${ }^{126}$

\section{FEASIBILITY}

Proposing the creation of a fourth branch of government will produce snickers in any knowledgeable audience and puzzled frowns elsewhere. Many Americans have heard about the branches, checks, and balances from an early age, even if they do not have a very clear idea of the specifics. Even people with no exposure to "civics" are quick to agree that politicians are corrupt-but what they imagine is bribery: trash bags filled with cash, delivered in dark alleys, or vacation condos on exotic islands. Explaining the problem and costs of "lawful corruption," how it arises despite the Madisonian checks and balances, how it ensnares well-meaning elected officials, and why interdiction of its effects is likely more effective than reforms aimed at causation, requires a multidisciplinary educational process. However, economic analysis yields the most convincing argument for the feasibility of reform.

Elites engage in costly efforts to influence policy to advance their own interests and to defend against encroachments from rival elites. The result is an escalating spiral of expenditure by each elite interest and consequent corrupt reductions in the general welfare, affecting not just those without influence but also other, unrelated, elite interests. Elected officials are trapped in this gyre no less than the elites. If government were immune to such influence, fewer of these expenditures would be necessary or worthwhile, and the extent of corrupt influence would decline. It is not possible, or even desirable, to make elected officials immune to elite influence because that could be done only by making them immune to all influences. However, it is possible to reduce the cumulative and escalating adverse impact of this process on everyone, elites and non-elites alike. The key is to rule out elite-favored ends that reduce the size of the pie. This leaves elites

${ }^{126}$ If Congress wished to punish or intimidate the Council, cutting or eliminating its budget might be a temptation. A similar issue could arise with the Supreme Court, although there is little or no indication that it ever has. One way to guard against such a threat is to set a minimum level of appropriation - in effect, an entitlement - that does not have to pass through the usual annual appropriations process. The minimum could be set by linking to the budget of the Congress itself. 
free to use government to steal from each other, subject to the constraint that the pie as a whole may not be reduced by the policies they promote. Only shares of the pie, and not the size of the pie, are then at risk. Other elites have resources worth stealing, while the poor have little to steal. The share of the middle class remains vulnerable, through tax policy for example, but it can fight back with its greater numbers and passionate causes.

Given the difficulty faced by elites collectively in containing their potentially destabilizing and pie-shrinking greed, it seems likely that an Umpire Amendment also is in the collective interest of the elite. ${ }^{127}$ Both politicians and elites today face a situation in which it is in the collective interest of each to promote reform. Neither group can do this successfully on an individual basis because there is no way any individual elite interest or politician can commit credibly to avoid future welfare-reducing corruption. The Umpire Amendment, unlike any act of Congress, is a very firm commitment.

${ }^{127}$ See Feuer, supra note 11. 
